\title{
Using modern low-oxygen marine ecosystems to understand the nitrogen cycle of the Paleo- and Mesoproterozoic oceans
}

\author{
Clara A. Fuchsman ${ }^{1 *}$ and Eva E. Stüeken ${ }^{2}$
}

1. University of Maryland Horn Point Laboratory, Cambridge MD 21613 USA

2. School of Earth \& Environmental Sciences, University of St Andrews, St Andrews KY16 9AL, Scotland, UK

*Corresponding author:

Clara Fuchsman

2020 Horns Point Rd

University of Maryland Horn Point Laboratory

Cambridge MD 21613 USA

Email: cfuchsman@umces.edu

Telephone: (410) 221-8382

Published in: Environmental Microbiology, doi:10.1111/1462-2920.15220

\section{Significance Statement}

This review combines data from modern Oxygen Minimum Zones and data from the marine sedimentary rock record, bringing together two disparate communities and providing a new perspective on the Proterozoic ecosystem.

\section{Summary}

During the productive Paleoproterozoic (2.4-1.8 Ga) and less productive Mesoproterozoic (1.8 to $1.0 \mathrm{Ga}$ ), the ocean was suboxic to anoxic and multicellular organisms had not yet evolved. Here we link geologic information about the Proterozoic ocean to microbial processes in modern low oxygen systems. High iron concentrations and rates of Fe cycling in the Proterozoic are the largest differences from modern oxygen deficient zones. In anoxic waters, which composed most of the Paleoproterozoic and $\sim 40 \%$ of the Mesoproterozoic ocean, nitrogen cycling dominated. Rates of $\mathrm{N}_{2}$ production by denitrification and anammox were likely linked to sinking organic matter fluxes and in situ primary productivity under anoxic conditions. Additionally autotrophic denitrifiers could have used reduced iron or methane. $50 \%$ of the Mesoproterozoic ocean may have been suboxic, promoting nitrification and metal oxidation in the suboxic water and $\mathrm{N}_{2} \mathrm{O}$ and $\mathrm{N}_{2}$ production by partial and complete denitrification in anoxic zones in organic aggregates. Sulfidic conditions may have composed $\sim 10 \%$ of the Mesoproterozoic ocean focused along continental margins. Due to low nitrate concentrations in offshore regions, anammox bacteria likely dominated $\mathrm{N}_{2}$ production immediately above sulfidic zones, but in coastal regions, higher nitrate concentrations probably promoted complete S-oxidizing autotrophic denitrification at the sulfide interface. 


\section{Introduction}

The last two decades have witnessed ever more refined studies of biogeochemical cycles on the Precambrian Earth with expanding applications of novel isotopic proxies (Kendall et al., 2017; Stüeken, 2017; F. Zhang et al., 2020) and increasingly sophisticated computational models (Olson et al., 2013; Reinhard et al., 2016; Laakso and Schrag, 2017). These studies have uncovered temporal and spatial nuances in seawater oxygenation and revealed feedbacks between tectonic, climatic and biological processes (Mills et al., 2014; Lee et al., 2016; Husson and Peters, 2017). At the same time, oceanographers and microbiologists have been advancing our understanding of the marine nitrogen cycle in a range of redox conditions that are analogous to the early Earth (Babbin et al., 2014; Devol, 2015; Bristow et al., 2016; Oschlies et al., 2019). However, linkages between the two communities of researchers are rare (Michiels et al., 2017; Schad et al., 2019). Here we bridge this gap with a review of modern nitrogen metabolisms linked to Earth's environmental history over geologic timescales.

\section{The redox evolution of Earth's ocean and atmosphere}

The emergence of cyanobacteria capable of performing oxygenic photosynthesis $>3.0$ billion years ago (Ga) (Planavsky, Asael, et al., 2014) has profoundly impacted the evolution of biogeochemical cycles. However, the transition towards a fully oxygenated world unfolded slowly over geologic time (Figure 1). Until the end of the Archaean (4.0-2.5 Ga), Earth's ocean and atmosphere were largely anoxic (Lyons et al., 2014). Evidence for this view comes from photochemically-produced mass independent fractionation of sulfur isotopes in Archaean sedimentary rocks (Farquhar et al., 2001). This signal is erased by small oxygen concentrations, indicating that the atmosphere contained $<1 \mathrm{ppm} \mathrm{O}_{2}$ until the beginning of the Paleoproterozoic around 2.4-2.3 Ga (Farquhar et al., 2001; Pavlov and Kasting, 2002; Guo et al., 2009). Under these anoxic conditions, methane was probably more stable in the atmosphere and may have contributed to greenhouse warming (Haqq-Misra et al., 2008; Laakso and Schrag, 2019). Oceanic iron concentrations, specifically ferrous iron, were likely much higher in the Archaean than today, as evidenced by abundant banded iron formations (James and Trendall, 1982; Konhauser et al., 2017). Ocean waters were thus ferruginous. Some of this ferrous iron likely fuelled anoxygenic photosynthesis, called photoferrotrophy, which may have been the main mechanism for driving iron oxidation in the Archean (Widdel et al., 1993; Kappler and Pasquero, 2005; Crowe et al., 2008; Butterfield, 2015; Camacho et al., 2017; Thompson et al., 2019). Cyanobacteria probably produced oxygen in the marine euphotic zone, and, at least during the late Archaean, may have created "oxygen oases" in surface waters (Koehler et al., 2018) as well as temporary whiffs of oxygen in the atmosphere (Anbar et al., 2007). Microbial mats on land may have contained oxygen-producing cyanobacteria as well (Lalonde and Konhauser, 2014), which could have created a small flux of fixed nitrogen and oxidized sulfur to the ocean (Stuieken et al., 2012; Thomazo et al., 2018). It is thought that reservoirs of reduced species (iron, sulfur, carbon and hydrogen) at the Earth's surface had to be either oxidized by oxygen, buried in the mantle, or lost to space before free $\mathrm{O}_{2}$ gas could build up in the atmosphere (Catling, 2014).

The Paleoproterozoic (2.4-1.6 Ga) saw the rise of atmospheric oxygen, perhaps even briefly up to modern levels (Bekker and Holland, 2012; Partin et al., 2013). The presence of oxygen likely placed a strong upper limit on the greenhouse gas methane, potentially causing the global glaciations documented from the Paleoproterozoic (Haqq-Misra et al., 2008; Olson et al., 2016; Gumsley et al., 2017). Higher oxygen levels likely also spurred the oxidation of pyrite on land, releasing sulfuric acid (Konhauser et al., 2011), which would have both added sulfur to the ocean (Blättler et al., 2018) and decreased the $\mathrm{pH}$ of soils (Konhauser et al., 2011). It has been proposed that acidic waters may have resulted in a enhanced phosphorus release from apatite on land, which could explain the first occurrences of large phosphorite deposits at this time (Bekker and Holland 2012). Weathering rates may have been 
twice as high as today (Bekker and Holland, 2012). This increase in the essential nutrient phosphate may have enhanced biological productivity in the ocean and caused intense organic carbon burial, consistent with a large positive excursion in carbon isotopes seen in the later part of the Paleoproterozoic (Lomagundi-Jatuli event, 2.3-2.1 Ga; Martin et al., 2013). During the Paleoproterozoic, the deep ocean may have experienced at least brief episodes of oxygenation between 2.0-1.85 Ga (Kipp et al., 2017, 2020; Planavsky et al., 2018; Mänd et al., 2020), but it likely returned to a mostly anoxic state after this interval (Kendall et al., 2011). Incomplete oxygenation of the ocean at this time may place an upper limit on atmospheric oxygen levels (Kipp et al., 2017). Alternatively, it is possible that warm temperatures before and after glacial events prevented efficient mixing of the water column, or that the flux of reductants from volcanic activity on the seafloor acted as a strong oxygen sink (Ossa et al., 2018). Marine cyanobacteria were probably the main photosynthesizers in the Paleo- and Mesoproterozoic, although anoxic photosynthesizers using reduced iron or sulfide could also have played a role, particularly deeper in the photic zone close to the interface between oxic surface waters and anoxic deep waters (Johnston et al., 2009; Butterfield, 2015; Camacho et al., 2017; Thompson et al., 2019). While modern unicellular cyanobacteria (Synechococcus and Prochlorococcus) probably did not evolve until the Neoproterozoic (Sánchez-Baracaldo, 2015), unicellular cyanobacteria did exist in the Paleo- and Mesoproterozoic and would likely have filled their niche (Butterfield, 2015).

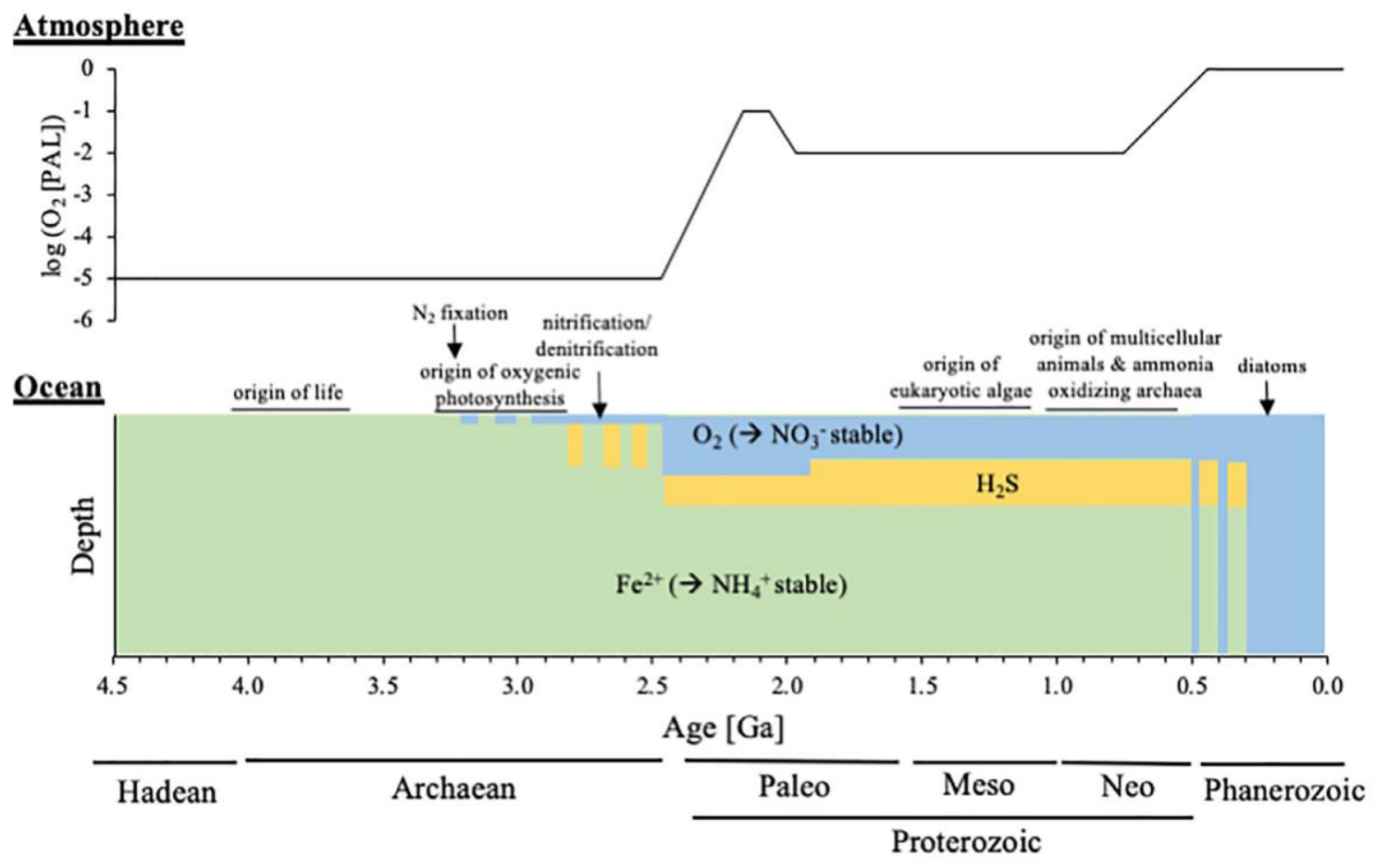

Figure 1: Timeline of earth's history with atmospheric oxygen concentrations in PAL (present atmospheric levels) indicated in the upper panel and oceanic chemistry indicated in the lower panel. Green, yellow and blue indicate ferruginous, sulfidic, and oxygenated conditions respectively. Important events in organism evolution are indicated.

Throughout the Mesoproterozoic $(1.6$ - $1.0 \mathrm{Ga})$, the deep ocean continued to be dominated by ferruginous ( $\mathrm{Fe}^{2+}$-rich) conditions (Planavsky et al., 2011; Poulton and Canfield, 2011; Sperling et al., 2015) while the surface ocean and atmosphere were oxygenated (Hardisty et al., 2017). Temperatures were temperate during this interval with no evidence of glaciations, although the mechanism to maintain these warm temperatures is still debated (Buick, 2007; Roberson et al., 2011; Olson et al., 2016; Zhao et 
al., 2018). Oxygen concentrations in the atmosphere for the Mesoproterozoic are controversial. While some datasets are consistent with as little as $0.1 \%$ of present atmospheric levels (Planavsky, Reinhard, et al., 2014; Planavsky et al., 2020), others suggest 1-10\% (Daines et al., 2017). It is also conceivable that oxygen levels were variable through time and space (Diamond and Lyons, 2018; Shang et al., 2019; Steadman et al., 2020). The oxygen concentrations could have decreased from the Paleoproterozoic to the Mesoproterozoic due to weathering of organic rich sedimentary rocks deposited during the Lomagundi-Jatuly event at the end of the Paleoproterozoic (Kump et al., 2011) and then stayed low due to reduced weathering in a negative feedback loop (Daines et al., 2017). Productivity estimates from sulfate ${ }^{17} \mathrm{O}$ isotopes indicate that productivity rates may have been as low as $6 \%$ of modern levels during the Mesoproterozoic (Crockford et al., 2018), possibly due to severe phosphorus limitation (Reinhard et al., 2017). Phosphorus is scavenged by iron-carbonate minerals under ferruginous conditions (Derry, 2015). Coupled chromium and molybdenum data indicate that at least 30-40\% and possibly as much as $100 \%$ of the deep ocean was anoxic and mostly ferruginous during this time, and up to $10 \%$ of seafloor was covered by euxinic waters (anoxic with $>11 \mu \mathrm{M}$ free $\mathrm{H}_{2} \mathrm{~S}$ ) compared to $0.1 \%$ today (Reinhard et al., 2013). This redox landscape thus greatly limited the marine $P$ reservoir and suppressed productivity. The sulfidic waters probably extended mostly as wedges in upwelling zones along outer continental shelves above ferruginous bottom waters (Poulton et al., 2010) (Figure 1). In such upwelling regions, nutrient availability would have been highest. The mechanism for this midwater sulfide zone is thus probably similar to that creating midwater oxygen minimum zones in the modern ocean (Lyons et al., 2014). Aerobic degradation of organic particulates is highest in the upper ocean, thus oxygen is depleted in intermediate waters. However, the sinking flux is still significant, and because in the Proterozoic $\mathrm{O}_{2}$ was not replenished by upwelling of oxic waters - as is the case today - conditions became highly anoxic at mid-depth. In deep waters, the sinking flux of organic matter was probably largely attenuated, such that conditions "relaxed" from euxinic to ferruginous.

Atmospheric oxygen levels likely rose to modern levels in the Neoproterozoic (1.0 to $0.54 \mathrm{Ga}$; Shields-Zhou et al., 2011) or mid-Paleozoic (0.54-0.25 Ga), following the rise of land plants (Lenton et al., 2016; Krause et al., 2018) and the expansion of burrowing organisms and planktonic algae (Lu et al., 2018; Tarhan, 2018). Until then, at least parts of the deep ocean likely continued to be anoxic and ferruginous with occasional euxinic intervals (Stockey et al., 2020).

\section{Precambrian records of the biogeochemical nitrogen cycle}

Geochemists commonly use nitrogen isotopic ratios preserved in sedimentary rocks to determine which $\mathrm{N}$ cycling metabolisms were active in the past (reviewed by (Ader et al., 2016; Stiueken et al., 2016)). The two stable isotopes of nitrogen $\left({ }^{15} \mathrm{~N}\right.$ and ${ }^{14} \mathrm{~N}$ ) are fractionated by several permil during most metabolic pathways, and the biomass of living organisms that gets buried in sediments preserves ${ }^{15} \mathrm{~N} /{ }^{14} \mathrm{~N}$ ratios (expressed as $\delta^{15} \mathrm{~N}[\% 0]=\left({ }^{15} \mathrm{~N} /{ }^{14} \mathrm{~N}\right)_{\text {sample }} /\left({ }^{15} \mathrm{~N} /{ }^{14} \mathrm{~N}\right)$ air -1$)$ characteristic of its major $\mathrm{N}$ source. An important aspect to keep in mind when interpreting these records is that nitrogen is mobile during diagenesis. Measured ${ }^{15} \mathrm{~N} /{ }^{14} \mathrm{~N}$ ratios in rock samples therefore typically capture a bulk average value of all biomass present in the sample, meaning that only the most dominant $\mathrm{N}$ metabolisms are preserved. Intricate metabolic networks remain elusive.

When applied to sedimentary rocks from the Archean, this approach revealed $\delta^{15} \mathrm{~N}$ values around $0 \%$, consistent with significant degrees of biological $\mathrm{N}_{2}$ fixation (Stüeken et al., 2015). Importantly, the predominant enzyme appears to have been molybdenum-iron nitrogenase; alternative nitrogenases based on Fe or V impart larger fractionations (Zhang et al., 2014) that are inconsistent with the Archean record (Stuieken et al., 2015). This result is interesting since Mo concentrations were significantly lower in the Archean and Proterozoic due to widely anoxic conditions (5-10 nM instead of $105 \mathrm{nM}$; Reinhard et al., 2013) whereas oceanic iron concentrations were much higher than today $(0.1-1 \mathrm{mM}$ instead of $\sim 1 \mathrm{nM}$; Holland, 1984; Derry, 2015; Tosca et al., 2016). However, the molybdenum-iron nitrogenase is significantly more efficient than alternative nitrogenases (Eady, 1996), and even low Mo levels are 
sufficient to support at least low rates of $\mathrm{N}_{2}$ fixation in modern organisms (Zerkle et al., 2006; Glass et al., 2009), and it is conceivable that early diazotrophs were adapted to lower Mo concentrations. Hence microbial metabolisms have likely been capable of transforming atmospheric $\mathrm{N}_{2}$ into ammonium since the early Archean (Stüeken et al., 2016).

In the late Archaean, nitrogen stable isotopes started to show more variability. Negative $\delta^{15} \mathrm{~N}$ values, which would indicate partial ammonium assimilation, are restricted to few sites in the late Archaean (Yang et al., 2019), indicating that dissolved ammonium levels were usually below a few $\mu \mathrm{M}$ in the global ocean (Stüeken et al., 2016; Koehler et al., 2019). Rocks from around 2.6 Ga show a 6\% increase in the $\delta^{15} \mathrm{~N}$ of kerogen, indicating that light $\mathrm{N}$ was preferentially lost from the ocean, which is most parsimoninously explained by nitrate reduction to $\mathrm{N}_{2}$ gas (denitrification), similar to the modern ocean (Godfrey and Falkowski, 2009; Koehler et al., 2018). Denitrification requires the presence of nitrate, which in turn requires the presence of oxygen to oxidize ammonium (nitrification). These data are thus consistent with at least transiently oxic conditions in the surface ocean at that time. Positive $\delta^{15} \mathrm{~N}$ values became more widespread in Paleoproterozoic marine sedimentary rocks, indicating that denitrification (and by extension nitrate) became widely bioavailable during that time period (Zerkle $e t$ al., 2017; Kipp et al., 2018; Luo et al., 2018; Cheng et al., 2019). In contrast, during the Mesoproterozoic when oxygen concentrations were perhaps again slightly lower, positive $\delta^{15} \mathrm{~N}$ values are restricted to a few basins, and often to shallow-marine settings (Stüeken, 2013; Koehler et al., 2017; Wang et al., 2020). This patterns has been interpreted as a gradient in seawater nitrate levels from onshore (high) to offshore (low). Several perturbations in $\delta^{15} \mathrm{~N}$ are recorded in the Neoproterozoic and throughout the Phanerozoic, possibly driven by a combination of redox changes, biological evolution and global climatic shifts (Ader et al., 2014; Algeo et al., 2014; Johnson et al., 2017; Wang et al., 2018).

Although a billion years of evolution has occurred since the Paleo- and Mesoproterozoic, the geological record suggests that biological $\mathrm{N}_{2}$ fixation, ammonium assimilation, nitrification and denitrificaiton, i.e. the major metabolic pathways that close the nitrogen cycle, had evolved by the Proterozoic (Figure 1). However, it is important to stress that sedimentary $\delta^{15} \mathrm{~N}$ of ancient biomass cannot distinguish between canonical denitrificaiton (nitrate reduced to $\mathrm{N}_{2}$ coupled to oxidation of organic matter, ferrous iron or sulfide), anaerobic ammonium oxidation (anammox, which couples nitrate reduction to ammonium oxidation) and dissimilatory nitrate reduction to ammonium (DNRA). Isotopic fractionations imparted by these three pathways are too similar. To elucidate this knowledge gap and to provide better constraints on interpretations of ancient nitrogen isotope records, we combine information about carbon and nitrogen cycling and microbial ecology of modern low oxygen regions with our knowledge of the Paleo- and Mesoproterozoic.

\section{Sources and sinks of nitrogen in the modern ocean}

The major source of fixed nitrogen is biological $\mathrm{N}_{2}$ fixation, which is mostly carried out by cyanobacteria in the photic zone (Montoya et al., 2004; Moisander et al., 2010; Zehr, 2011). In anoxic waters where sulfide is present, such as in the Black Sea or the Baltic Sea, anaerobic organisms such as sulfate reducers or $\mathrm{S}$ oxidizers are the major $\mathrm{N}_{2}$ fixers (Fernandez et al., 2011; Farnelid et al., 2013; Kirkpatrick et al., 2018) and at methane seeps, methanogens can be the main $\mathrm{N}_{2}$ fixers (Dekas et al., 2009). It is not known which organisms were the major diazotrophs in the Precambrian, but these modern observations from anoxic zones support the inference that the evolution of cyanobacteria was not a necessary requirement for wide-spread $\mathrm{N}_{2}$ fixation. Fixed nitrogen is converted to ammonium during biomass degradation, and ammonium is stable in anoxic waters (Brewer and Murray, 1973). However, in the modern oxic ocean, most dissolved nitrogen is present in the form of nitrate.

Nitrate is formed by the sequential processess of ammonium oxidation and nitrite oxidation by specific chemoautotrophs, which can proceed at low oxygen concentrations down to a few $\mathrm{nM}$ (Lipschultz et al., 1990; Bristow et al., 2016). Ammonium and nitrite oxidation do need ammonium to 
be produced from organic matter remineralization. In the modern oxic ocean, these chemoautotrophs fix $\sim 10^{13}$ mol of organic $\mathrm{C}$ per year and thus are a significant source of organic carbon to the ecosystem (Y. Zhang et al., 2020). The half saturation constant $\left(\mathrm{K}_{\mathrm{m}}\right)$ for nitrite oxidation at low oxygen is $0.5 \pm 4.0 \mathrm{nM}$ $\mathrm{O}_{2}$ (from two component fitting), which implies that nitrite oxidation can occur at oxygen concentrations below our ability to measure oxygen (Bristow et al., 2016). Stable $\delta^{15} \mathrm{~N}$ and $\delta^{18} \mathrm{O}$ isotopes indicate that both nitrite oxidation and dentrification occur in ODZs (Gaye et al., 2013; Buchwald et al., 2015; Peters et al., 2016; Martin and Casciotti, 2017). Shipboard nitrite oxidation rates have been measured from oxygen deficient waters, and anaerobic nitrite oxidation through an unknown mechanism has even been proposed (Babbin et al., 2017, 2020; Sun et al., 2017, 2019). However, oxygen contamination at subnanomolar concentrations is quite difficult to avoid in experiments, so the mechanism involved in this oxidation remains elusive.

Ammonium oxidation to nitrite can be mediated by ammonia oxidizing archaea (Thaumarcheota) or ammonia oxidizing bacteria. However, the vast majority of ammonium oxidation in the modern marine water column is mediated by archaea (Martens-Habbena et al., 2015; Peng et al., 2015; Horak et al., 2018) because these organisms have a greater ability to scavenge low concentrations of ammonium (Martens-Habbena et al., 2009). For ammonia oxidizing archaea the half saturation constant $\left(\mathrm{K}_{\mathrm{m}}\right)$ for oxygen is $333 \pm 130 \mathrm{nM} \mathrm{O}_{2}$ (Bristow et al., 2016), preventing oxic ammonium oxidation from occurring in anoxic ODZs, where oxygen is $<10 \mathrm{nM}$ (Revsbech et al., 2009), but allowing it in suboxic waters, where oxygen is $<10 \mu \mathrm{M}$. Ammonia oxidation in the oxycline surrounding ODZs was mediated by archaea (Peng et al., 2015). In suboxic regions above sulfidic zones, where ammonium fluxes are high (Fuchsman et al., 2008), both archaea and bacteria have been implicated in ammonia oxidation (Lam et al., 2007; Cernadas-Martín et al., 2017). Ammonium oxidation by either archaea or bacteria produces $\mathrm{N}_{2} \mathrm{O}$ as a by-product under low oxygen conditions; however ammonium oxidation by cultured proteobacteria (Goreau et al., 1980; Kozlowski, Kits, et al., 2016) produce at least ten fold more $\mathrm{N}_{2} \mathrm{O}$ yield under low oxygen conditions than natural populations of archaea (Hink et al., 2017; Ji et al., 2018). The conversion from $\mathrm{NO}$ to $\mathrm{N}_{2} \mathrm{O}$ is enzymatic in some ammonia oxidizing bacteria but abiotic in others and is abiotic for ammonia oxidizing archaea (Kozlowski, Kits, et al., 2016; Kozlowski, Stieglmeier, et al., 2016). Horizontal gene transfer from bacteria was probably necessary for Thaumarcheota to adapt from hyperthermophilic ancestors to the cold deep ocean (Brochier-Armanet et al., 2011), and it is thought that Thaumarcheota did not spread to the marine environment until the Neoproterozoic (Ren $e t$ al., 2019). Hence, unlike the modern ocean, bacteria likely mediated ammonium oxidation during the Paleo- and Mesoproterozoic. Bacterial ammonia oxidizers need higher concentrations of ammonium than do ammonia oxidizing archaea. The ability to scavenge low concentrations of ammonium may not necessarily have been evolutionarily advantageous in the Proterozoic, when the deep ocean was anoxic and ammonium-rich compared to today (up to $\sim 10 \mu \mathrm{M}$; Stüeken et al., 2016; Koehler et al., 2019). Ammonia oxidizing bacteria are found in several distinct groups of bacteria including betaproteobacteria, gammaproteobacteria and Nitrospirae, though ammonium oxidizing Nitrospirae have not been found in the marine environment (Kits et al., 2019). Since $\mathrm{N}_{2} \mathrm{O}$ yields for beta and gammaproteobacteria are high (Goreau et al., 1980; Kozlowski, Kits, et al., 2016), we predict that the ancestral ammonia oxidizing bacteria produced significant amounts of $\mathrm{N}_{2} \mathrm{O}$ under suboxic conditions in the Proterozoic.

There are three known and potentially competing pathways that lead to loss of fixed nitrogen from the ocean (which today is mostly in the form of nitrate): heterotrophic denitrification, autotrophic denitrification, and anammox. In both heterotrophic and autotrophic denitrification, nitrate is reduced using the same pathway.

$\mathrm{NO}_{3}{ }^{-} \rightarrow \mathrm{NO}_{2}{ }^{-} \rightarrow \mathrm{NO}_{(\mathrm{g})} \rightarrow \mathrm{N}_{2} \mathrm{O}_{(\mathrm{g})} \rightarrow \mathrm{N}_{2}(\mathrm{~g})$

Heterotrophic denitrifiers use organic carbon as their reductant and have been preferentially found in particles suspended in the marine water column (Ganesh et al., 2014, 2015; Fuchsman et al., 2017). Autotrophic denitrifiers use ferrous iron (He et al., 2016), methane (Ettwig et al., 2010; Thamdrup et al., 2019) or sulfur compounds such as hydrogen sulfide, elemental sulfur and thiosulfate (Takai et al., 
2006). S-oxidizing autotrophic denitrifiers have been found together with sulfate reducers in particles in non-sulfidic conditions (Fuchsman, Murray, et al., 2012; Fuchsman et al., 2017; Saunders et al., 2019) and in the water column at sulfide interfaces (Hannig et al., 2007; Jensen et al., 2009; Lavik et al., 2009; Fuchsman, Murray, et al., 2012). Autotrophic denitrification with methane has also been found in anoxic waters (Ettwig et al., 2010; Thamdrup et al., 2019). All of these reductants (organic matter, methane, reduce sulfur, ferrous iron) would have been present in the anoxic Precambrian ocean, meaning that denitrification is unlikely to have been starved of reductant. Anammox is an autotrophic process where $\mathrm{NH}_{4}{ }^{+}+\mathrm{NO}_{2}{ }^{-} \rightarrow \mathrm{N}_{2}+2 \mathrm{H}_{2} \mathrm{O}$ via a hydrazine intermediate with no $\mathrm{N}_{2} \mathrm{O}$ produced (van de Graaf et al., 1996, 1997). Anammox bacteria, known to be slow-growing (Strous et al., 1999), have been found to have a free-living lifestyle in anoxic marine water columns (Fuchsman, Staley, et al., 2012; Ganesh et al., 2014). They may thus have been present along with denitrifiers in the Proterozoic ocean.

In all three major marine oxygen deficient zones (ODZs), the Arabian Sea, the Eastern Tropical North Pacific (ETNP) and the Eastern Tropical South Pacific (ETSP), heterotrophic denitrification and anammox rates significantly increased with the addition of sterilized sediment trap organic matter (Ward et al., 2008; Babbin et al., 2014; Chang et al., 2014), and removal of all particles decreased rates of both anammox and denitrification (Ganesh et al., 2015). Despite anammox bacteria being free-living organisms (Fuchsman et al., 2012; Ganesh et al., 2014), anammox rates correlate with particulate matter flux (Kalvelage et al., 2013). This correlation likely arises because dissolved ammonium is typically < $10 \mathrm{nM}$ in ODZs (Widner, Fuchsman, et al., 2018; Widner, Mordy, et al., 2018), and so anammox bacteria use ammonium produced in situ from organic matter remineralization (Devol, 2003). This dependence on remineralization of organic matter means that anammox rates should only be $\sim 30 \%$ of the total $\mathrm{N}_{2}$ production in modern ODZs (Devol, 2003). However, the presence of nitrite oxidation can short circuit denitrification, allowing a somewhat higher percentage (Penn et al., 2016; Babbin et al., 2020). In anoxic Proterozoic waters, ammonium may have been more widely available, preventing the tight coupling of anammox with organic matter.

Nitrate reduction can also lead to dissimilatory nitrate reduction to ammonium (DNRA). We note that DNRA is a process that removes nitrate, but since it produces ammonium, the net amount of fixed nitrogen does not change. DNRA is very important in coastal sediments under ODZs where it is mediated by giant sulfur bacteria and linked to S oxidation (Bohlen et al., 2011; Dale et al., 2016). The ammonium from DNRA can fuel anammox or photosynthesizers in the water column in these coastal systems (Lam et al., 2009; Dale et al., 2016; Michiels et al., 2017). DNRA has been measured in the coastal ODZs (Lam et al., 2009; Jensen et al., 2011). However, in general DNRA seems to be unimportant in pelagic ODZs (Ganesh et al., 2015; Fuchsman et al., 2017; Zakem et al., 2020) or in suboxic waters above sulfidic zones (Bonaglia et al., 2016). The mechanisms to explain why DNRA is sometimes important compared to denitrification are not well understood, but culture work and energetic calculations indicate that denitrification is favored over heterotrophic DNRA if organic matter is limiting and DNRA is favored if nitrate is limiting (Strohm et al., 2007). This relationship would be consistent with DNRA being found only in coastal ODZs, where organic matter concentrations are high. It may also suggest that DNRA was favored in the Proterozoic where nitrate levels were probably lower than today (Stuieken, 2013; Koehler et al., 2017; Wang et al., 2020). This view is supported by observations from a modern ferruginous lake where DNRA appears to be favored over denitrification and is stimulated by iron (Michiels et al., 2017).

\section{The effect of high iron concentrations on anoxic microbial communities}

The ancient ocean was ferruginous, unlike the modern ocean where iron is usually at nanomolar to subnanomolar concentrations (Slemons et al., 2010) even in offshore ODZs (Kondo and Moffett, 2013, 2015) though iron concentrations are higher when anoxic water overlies the continental shelf (Heller et al., 2017; Scholz, 2018). Although the enrichment of iron in metalloenzymes found in ODZs likely reflect evolution in ferruginous conditions of the Archaean and Proterozoic (Glass et al., 2015), present 
conditions do not make ODZs a good proxy for iron cycling in the ancient ocean. A more appropriate modern analogue may be ferruginous lakes, which are sulfate poor (Crowe et al., 2008). Photoferrotrophy is important in ferruginous lakes with miniscule sulfate concentrations where the light can reach the chemocline (Walter et al., 2014; Llirós et al., 2015; Camacho et al., 2017; Thompson et al., 2019). Specific green sulfur bacteria, purple sulfur bacteria, and purple non-sulfur bacteria can mediate photoferrotrophy (Camacho et al., 2017). Cultures of purple sulfur bacteria have the highest rates of photoferrotrophy (Hegler et al., 2008). However, green sulfur bacteria, both types using iron or reduced sulfur, can grow slowly at very low light levels (<50 lux; Hegler et al., 2008; Marschall et al., 2010). Thus different photoferrotrophs have different niches. A danger of photoferrotrophy for a pelagic microbe is that the microbe will become encrusted with iron and sink out of the water column (Thompson et al., 2019). However, studied pelagic photoferrotrophs have a negative charge to their outer membrane, repelling the iron oxides, which typically have a negative surface charge (Thompson et al., 2019). The organic matter from these photoferrotrophs can then support methanogenesis at depth (Thompson et al., 2019), Interestingly, in anoxic lakes with even small sulfate and sulfide concentrations, anoxygenic photosynthesis with reduced sulfur is favored over photoferrotrophy $(\sim 1 \mu \mathrm{M}$ reduced $\mathrm{S}$; Crowe, Maresca, et al., 2014). Thus, although photoferrotrophy may have been the main mechanism for driving iron oxidation in the Archean (Kappler and Pasquero, 2005; Crowe et al., 2008; Butterfield, 2015; Camacho et al., 2017; Schad et al., 2019; Thompson et al., 2019) where sulfate concentrations were low (perhaps as low as $2.5 \mu \mathrm{M}$; Crowe, Paris, et al., 2014), photoferrotrophy was likely reduced in the Proterozoic where sulfate and reduced S were more plentiful (Scott et al., 2014; Luo et al., 2015). Additionally, the increase in cyanboacteria mediating oxic photosynthesis and the oxygen they produce would have pushed the photoferrotrophs deeper into the water column and further from light (Schad et al., 2019).

Iron cycling at neutral $\mathrm{pH}$ is still being investigated in the modern day. Iron can definitely be microbially reduced using organic matter or sulfide under anaerobic conditions (Burdige, 1993). Ferric iron reduction can also be coupled to ammonium oxidation to $\mathrm{N}_{2}(\mathrm{Fe}$-ammox) under high iron conditions (Li et al., 2015, 2018; Stüeken et al., 2016; Huang and Jaffé, 2018). On the other hand, reduced iron can be oxidized by microaerophilic iron oxidation (Singer et al., 2011; Barco et al., 2015; Chiu et al., 2017). Anaerobic iron oxidation, formerly thought to be mediated by heterotrophic denitrifiers, may in fact be abiotic iron oxidation, driven by the nitrite that accumulated during denitrification (Klueglein and Kappler, 2013). This abiotic process appears to be important when ODZs overlap with the shelf and iron concentrations are elevated due to upward diffusion of iron from sediments into the oxygen-depleted water column, but may even occur to some extent offshore (Scholz et al., 2016; Heller et al., 2017). Additionally, there is one cultured example of anoxic chemosynthetic iron oxidizer that reduces nitrate, a betaproteobacteria (Gallionellaceae) (Straub et al., 1996; He et al., 2016; Tominski et al., 2018). This culture reduces nitrate to nitrite and NO using iron, and other members of the community then reduce the $\mathrm{NO}$ to $\mathrm{N}_{2}$ gas (He et al., 2016). This iron mediated nitrate reduction has also been found in ferruginous lakes (Michiels et al., 2017). Iron can also be oxidized by sinking manganese oxides, though this may be abiotic (Dellwig et al., 2010). We would expect that under high iron conditions in the Proterozoic, iron would be microbially cycled through reduction using both organic matter and sulfide and oxidation using both oxygen, nitrate/nitrite, and photoferrotrophy. Similarly, oxidation of other metals, such as arsenic, may have contributed to chemoautotrophic nitrate reduction to nitrite (Saunders et al., 2019). Arsenic was also at much higher concentrations in the Proterozoic ocean (Bergman and Kolesov, 2012; Fru et al., 2015), and a complete arsenic redox cycle has been documented from ODZs even at modern low arsenic concentrations (Saunders et al., 2019). Thus, in general, metal cycling may have been more important in the Proterozoic ocean than seen in modern ODZs.

\section{Organic Matter}

The nitrogen cycle is intimately linked to the carbon cycle because organic matter provides a possible reductant for nitrate and other oxidized forms of $\mathrm{N}$, and because degradation of biomass releases 
ammonium into the water column. In the modern ocean, much of the flux of organic matter to depth is dependent on eukaryotic organisms. Large phytoplankton aggregate and sink (Smetacek, 1985; Guidi et al., 2009). Multicellular animals such as zooplankton or fish create fecal pellets that sink or swim to depth and deficate or excrete at depth (active transport) (Schnetzer and Steinberg, 2002; Steinberg et al., 2002). Zooplankton also consume and fragment particles, mediating 10\% of carbon flux attenuation in the open ocean (Dilling and Alldredge, 2000; Stukel et al., 2019). However, although eukaryotic algae first evolved in the Mesoproterozoic as coastal benthic species, they were marginalized until the Neoproterozoic, and the evolution of multicellular organisms occurred during the Neoproterozoic, perhaps due to higher oxygen concentrations (Butterfield, 2015). Protists that graze on bacteria had not yet evolved or were scarce during the Proterozoic (Butterfield, 2015) and some modern phytoplankton such as diatoms did not expand until the Mesozoic at which point the increasing sinking flux of organic matter may have contributed to further ocean oxygenation (Lu et al., 2018). The lack of mulicellular animals or large shelled eukaryotic algae in the Proterozoic may have reduced fast sinking fluxes from surface waters compared to today, but without zooplankton, all the sinking flux that did occur would have been consumed by microbes or buried. However, mineral ballast is not necessary for export of organic matter from the euphotic zone (Thomalla et al., 2008). Additionally, shelled organisms are not the only source of mineral ballast for sinking organic matter. Organic matter can pick up minerals such as carbonate or clay from the water column while sinking and these minerals causes the particles to be more dense and sink faster (Passow and De La Rocha, 2006). In cyanobacterial dominated oligotrophic waters, large particles appear to coalgulate from small $(20-200 \mu \mathrm{m})$ particles right below the mixed layer rather than leaving the mixed layer as large particles (Cavan et al., 2018).

The lack of protists does not necessarily mean that no predation occurred in the Proterozoic. In the present day, there are bacteria that predate on other bacteria. For example, Bdellovibrio enter the prey cell and consume it from the inside (Gophna et al., 2006); Myxococcus stalk their prey and secrete bacteriolytic enzymes that lyse their prey bacteria (Hillesland et al., 2007). These forms of predation are not nearly as efficient as the much larger filter feeding protists, however. Viruses, on the other hand, are thought to have evolved very early in Earth history (Hendrix et al., 2000), and can infect species on a large scale. In general, viral lysis releases cell contents into the water column, which may be a particularly important source of organic matter for the surrounding microbial community (Fuhrman, 1999; Shelford et al., 2012; Fang et al., 2019). However, viral infections are thought to be able to terminate phytoplankton blooms causing particle formation (Brussaard et al., 2005; Laber et al., 2018; Sheyn et al., 2018; Kranzler et al., 2019). Viral infection causes cells to produce sticky materials and aggregate, and infected bacteria have been seen to clump together forming small particles (Shibata et al., 1997). In the Eastern Tropical North Pacific ODZ, ODZ-specific cyanobacteria and their viruses were abundant on particles, implying the importance of viral infection on organic matter transfer in that system (Fuchsman, Palevsky, et al., 2019). Thus, viral infection may have been an important source of organic matter in the Proterozoic.

In a further complication, since some complex organic carbon is resistant to degradation under anoxic but not sulfidic conditions (Van Mooy et al., 2002), the scarcity of oxygen in the deep Proterozoic ocean would have limited respiration of organic carbon in the water column, which may have enhanced net export to the sediments (Van Mooy et al., 2002; Keil et al., 2016; Kipp and Stuieken, 2017). Overall, the mechanisms of the biological pump were different between the modern day and the Proterozoic, but transfer of organic matter to depth would still have occurred, providing reducing power and ammonium.

There is evidence of abundant phosphate and nitrate and large amounts of organic matter burial in the Paleoproterozoic (Bekker and Holland, 2012; Kipp and Stüeken, 2017; Kipp et al., 2018). Presumably the ocean had rampant primary productivity and abundant organic matter fluxes during this time period. The Mesoproterozoic, on the other hand, is thought to have experienceed greatly reduced nitrate and phosphate levels and greatly reduced primary productivity and organic matter burial (Bekker and Holland, 2012; Kipp and Stüeken, 2017; Koehler et al., 2017; Reinhard et al., 2017; Crockford et 
al., 2018). Thus we can broadly think of the Mesoproterozoic ocean as operating under oligotrophic conditions (Crockford et al., 2018).

A large percent of the volume of modern oxygen deficient zones, especially in the Eastern Tropical North Pacific (ETNP), are under oligotrophic surface waters (Pennington et al., 2006; Fuchsman, Palevsky, et al., 2019). Primary productivity is low and cyanobacteria and tiny eukaryotic plankton such as green algae dominate surface waters in this region (Pennington et al., 2006; Fuchsman, Palevsky, et al., 2019). Rather than aggregates of large phytoplankton with mineral ballast sinking from surface waters, large particles in this region coalgulated from small $(20-200 \mu \mathrm{m})$ particles right below the mixed layer (Cavan et al., 2018), and fluxes from the surface waters are low (Cavan et al., 2017; Fuchsman, Palevsky, et al., 2019). $\mathrm{N}_{2}$ production (by denitrification or anammox) is dependent on organic matter fluxes as heterotrophic denitrifiers directly utilize organic matter and anammox bacteria need the ammonium produced from organic matter degradation (Devol, 2003; Babbin et al., 2014; Chang et al., 2014; Ganesh et al., 2015). However, despite low fluxes from surface waters, $\mathrm{N}_{2}$ production occurs in the oligotrophic ETNP (Babbin et al., 2014, 2015; Fuchsman, Palevsky, et al., 2019).

One reason for this $\mathrm{N}_{2}$ production under oligotrophic surface waters could be the supply of organic matter by active cyanobacteria in the ODZ at extremely low light levels (1\% blue light; CepedaMorales et al., 2009). In much of the Eastern Tropical North Pacific, a secondary chlorophyll maximum of low light adapted cyanobacteria photosynthesize inside the oxygen deficient zone providing organic matter straight to anaerobic bacteria (Cepeda-Morales et al., 2009; Garcia-Robledo et al., 2017; Fuchsman, Palevsky, et al., 2019). ODZ cyanobacteria potentially provide up to $40 \%$ of the organic matter flux to the upper layer of the ODZ (Fuchsman, Palevsky, et al., 2019) and provide oxygen to oxygen-utilizing microbes under anoxic conditions (Garcia-Robledo et al., 2017). The presence of this cyanobacterial maximum in the ODZ is thought to be due to anoxic conditions preventing grazing on the cyanobacteria by oxygen-utilizing protists (Zakem et al., 2020). Similarly, anoxygenic photosynthesis with reduced $\mathrm{S}$ can occur at sulfidic zone boundaries (Marschall et al., 2010), or anoxygenic photosynthesis with reduced iron could occur under high iron conditions (Thompson et al., 2019). When primary production, either by cyanobacteria or anoxygenic photosynthesis, occured in the anoxic waters of the Proterozoic, the resulting organic matter could have fuelled anaerobic microbial processes without the need to form sinking particles. Solar irradience was reduced during the Mesoproterozoic compared to modern day (Gough, 1981), which would have affected the depth range of photosynthetic organisms. Since the light needed for photosynthesis in the anoxic zone is dependent on shading from shallower organisms and the depth of the upper boundary of anoxic water, it is hard to know how much primary production occurred in anoxic waters of the Proterozoic, but, like the modern ocean, the presence of primary producers in anoxic waters likely varied with space and time (Marquez-Artavia et al., 2019).

Photosynthesizers are not the only source of organic matter production under anoxic conditions. Additionally, above sulfidic zones, chemoautotrophic S-oxidizing bacteria can create an organic matter maximum at a sulfide interface (Glaubitz et al., 2010; Kirkpatrick et al., 2018; Scranton et al., 2020). These S-oxidizing bacteria may be autotrophic denitrifiers using nitrate, or they may use oxygen (Glaubitz et al., 2010; Kirkpatrick et al., 2018). Productivity rates at these organic matter maxima at sulfide boundaries can rival rates in surface waters (Yilmaz et al., 2006; Ediger et al., 2019). The organic matter created at these interfaces sinks into the sulfidic zone (Scranton et al., 2020) and thus fuels more sulfate reduction, leading to further organic matter recycling.

\section{N cycling under suboxic/hypoxic conditions}

Modelling and measurements have indicated that denitrification can occur inside particles under hypoxic conditions. $\mathrm{N}_{2} \mathrm{O}$ production and reduction are 50\% inhibited at 200 and $300 \mathrm{nM}$ oxygen respectively (Dalsgaard et al., 2014). However, there are oxygen gradients inside organic matter aggregates (Ploug et al., 1997; Ploug, 2001; Ploug and Bergkvist, 2015). Inside particles in fully oxygenated seawater, oxygen utilization is generally not limited by the transport of oxygen into the 
particle (Ploug, 2001). However, the potential for transport limitation of oxygen within particles, and therefore anoxia, is greatly dependent on particle size and ambient oxygen, with aggregates $>1 \mathrm{~mm}$ being much more susceptible to anoxia (Klawonn et al., 2015). In large aggregates, diffusion limitation of oxygen occurred below ambient $\mathrm{O}_{2}$ concentrations of $100 \mu \mathrm{M}$ (Ploug and Bergkvist, 2015; Stief et al., 2016), and at ambient $\mathrm{O}_{2}$ concentrations of $20 \mu \mathrm{M} \mathrm{O}_{2}, 50 \%$ of the interior of the aggregates became anoxic (Ploug and Bergkvist, 2015). In the marine environment, denitrification in aggregates, using $\mathrm{N}$ atoms originally from the particulate organic $\mathrm{N}$ and therefore oxidized in situ, has been detected at 30$50 \mu \mathrm{M}$ ambient $\mathrm{O}_{2}$ (Fuchsman, Paul, et al., 2019). Global modeling of aggregates in the ocean has indicated that inclusion of denitrification inside particles in suboxic waters would double estimates of modern marine water column denitrification rates (Bianchi et al., 2018). Thus, denitrification can occur in particles under suboxic conditions and with the same logic, sulfate reduction can occur in particles under nitrate conditions (Figure 2) and microbial evidence supports this idea (Fuchsman, Murray, et al., 2012; Saunders et al., 2019). We note, however, that in the modern ocean, particles created by picophytoplankton such as unicellular cyanobacteria are smaller than particles created by eukaryotic algae such as diatoms (Guidi et al., 2009). Thus, particles in the Proterozoic could potentially have been small and thus less limited by diffusion. However, oxygen concentrations were also quite low, which may have counter-balanced this size-limitation.
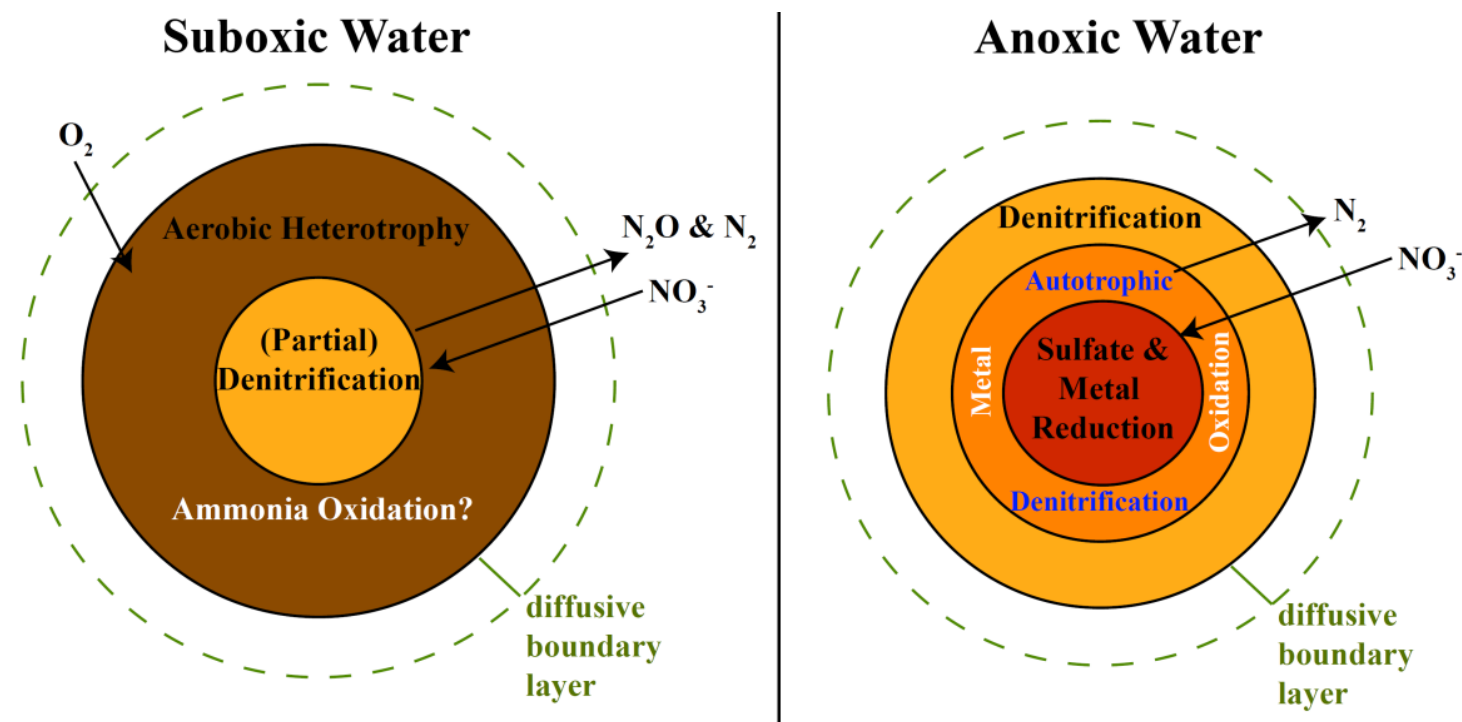

Figure 2: Schematic of the processes occurring inside particles under suboxic and anoxic conditions. The dashed line indicates the particles's diffusive boundary layer.

Suboxic waters may support oxic nitrogen cycling in the water column and denitrification in particles. The Bay of Bengal is a suboxic basin of the Indian Ocean with oxygen concentrations between 1-2 $\mu \mathrm{M}$ (Bristow et al., 2017). Neither anammox nor denitrification rates were detected in the water column but nitrite oxidation rates were high (Bristow et al., 2017). It has been suggested that nitrite oxidizers outcompete anammox for nitrite and/or ammonium under low oxygen (Bristow et al., 2017; Penn et al., 2019). 15N labeling, $\mathrm{N}_{2} \mathrm{O}$ stable isotopes and modelling indicated that a large proportion of $\mathrm{N}_{2} \mathrm{O}$ in the suboxic edge region above the ODZ is produced by denitrification (Babbin et al., 2015; Ji et al., 2015, 2018; Casciotti et al., 2018). One theory to explain the production of $\mathrm{N}_{2} \mathrm{O}$ from denitrification under suboxic conditions relates to small differences in the oxygen tolerance among steps in the denitrification pathway, with the last step being least tolerant (Babbin et al., 2015). $\mathrm{N}_{2} \mathrm{O}$ production by denitrification in these suboxic regions surrounding oxygen deficient zones may contribute $20 \%(0.5 \mathrm{Tg}$ $\mathrm{N}$ ) of marine $\mathrm{N}_{2} \mathrm{O}$ fluxes to the atmosphere $(2.8 \mathrm{Tg}-\mathrm{N})$ (Ji et al., 2018). However, denitrifier genes were only found in the particle fraction, not in the water column in the suboxic edge region of the ODZ, 
indicating that denitrification is particle-attached in these suboxic regions (Fuchsman et al., 2017). These $\mathrm{N}_{2} \mathrm{O}$ rate measurements (Babbin et al., 2015; Ji et al., 2015, 2018; Casciotti et al., 2018) were all obtained from offshore regions dominated by cyanobacteria where, presumably, the particles were small. In the suboxic zone below the ODZ, where particle fluxes are reduced, stable isotopes indicate that ammonium oxidation was the primary $\mathrm{N}_{2} \mathrm{O}$ source (Casciotti et al., 2018).

Table 1: Processes discussed in this paper compared between the modern and Proterozoic ocean. Cells indicate if these metabolisms are and were present in the suboxic $\left(<10 \mu \mathrm{M} \mathrm{O}_{2}\right)$ or anoxic $\left(<10 \mathrm{nM} \mathrm{O}_{2}\right)$ ocean.

\begin{tabular}{|c|c|c|c|c|c|c|}
\hline Process & Lifestyle & Modern suboxia & Modern anoxia & $\begin{array}{l}\text { Proterozoic } \\
\text { suboxia }\end{array}$ & Proterozoic anoxia & Implications \\
\hline Archaeal ammonia oxidation & Autotroph & $Y_{e s}{ }^{a}$ & $\mathrm{No}^{\mathrm{a}}$ & No & No & Possibly not yet evolved ${ }^{\mathrm{b}}$ \\
\hline Bacterial ammonia oxidation & Autotroph & $\begin{array}{l}\text { Black Sea but not } \\
\text { ODZs }\end{array}$ & No & Yes & No & $\begin{array}{l}\text { Need higher }\left[\mathrm{NH}_{4}{ }^{+}\right] \text {and makes more } \\
\mathrm{N}_{2} \mathrm{O} \text { than the archaea }{ }^{\mathrm{d}, \mathrm{e}}\end{array}$ \\
\hline Nitrite oxidation & Autotroph & Yes & At least at periphery & Yes & At least at periphery & $\begin{array}{l}\text { Produces nitrate. Uses } \mathrm{O}_{2} \text { at levels } \\
\text { below which we can measure.' }\end{array}$ \\
\hline Anammox & Autotroph & No (outcompeted) ${ }^{9}$ & Yes & No (outcompeted) & Yes & $\mathrm{N}_{2}$ producer \\
\hline Heterotrophic denitrification & Heterotroph & In particles & Yes & In particles & Yes & $\begin{array}{l}\mathrm{N}_{2} \text { producer. Produces } \mathrm{N}_{2} \mathrm{O} \text { under } \\
\text { suboxia.! }\end{array}$ \\
\hline Denitrification $\mathrm{w} / \mathrm{S}$ & Autotroph & No & $\begin{array}{r}\text { Sulfidic Zone } \\
\text { Boundary }\end{array}$ & No & $\begin{array}{l}\text { Sulfidic Zone } \\
\text { Boundary }\end{array}$ & $\mathrm{N}_{2}$ producer \\
\hline Denitrification w/methane & Autotroph & No & Low Levels' & No & Yes & $\mathrm{N}_{2}$ producer \\
\hline Denitrification w/iron & Autotroph & No & No & No & Yes & Higher iron concentrations in Proterozoic \\
\hline Fe-ammox & Autotroph & No & Sediments ${ }^{m}$ & No & Yes & Higher iron concentrations in Proterozoic \\
\hline DNRA & Heterotroph & No & Coastal $^{n}$ & No & Maybe $^{\circ}$ & Produces $\mathrm{NH}_{4}{ }^{+}$Factors still unclear \\
\hline DNRA w/S & Autotroph & No & Sulfidic sediments $^{p}$ & No & Sulfidic sediments & $\begin{array}{l}\text { Not likely in water column } 9 \text {. Produces } \\
\mathrm{NH}_{4}{ }^{+}\end{array}$ \\
\hline Photoferrotrophy & Autotroph & No & No & No & Yes $^{r}$ & $\begin{array}{l}\text { Needs light } \\
\text { Produces organic } C \text { at redox boundary }\end{array}$ \\
\hline $\begin{array}{l}\text { Anoxygenic photosynthesis } \\
\mathrm{w} / \mathrm{S}\end{array}$ & Autotroph & No & $\begin{array}{l}\text { Sulfidic zone } \\
\text { boundary }^{\text {s }}\end{array}$ & No & $\begin{array}{l}\text { Sulfidic zone } \\
\text { boundary }\end{array}$ & $\begin{array}{l}\text { Needs light } \\
\text { Produces organic } \mathrm{C} \text { at redox boundary }\end{array}$ \\
\hline Oxygenic photosynthesis & Autotroph & Yes & Yes $^{t}$ & Yes & Yes & $\begin{array}{l}\text { Needs light and } \mathrm{nNo} \text { sulfide } \\
\text { Produces organic C }\end{array}$ \\
\hline Iron reduction & Heterotroph & No & Sulfidic zones & No & Sulfidic zones & Source of reduced iron \\
\hline
\end{tabular}

Differences are in bold italics.

apeng et al. (2015).

${ }^{\mathrm{b}}$ Ren et al. (2019).

'Lam et al (2007).

dMartens-Habbena et al. (2009)

'Hink et al. (2017).

'Bristow et al. (2016).

'Bristow et al. (2017)

"Fuchsman et al. (2019a, 2019b).

'Fuchsman et al. (2017).

'Babbin et al. (2014).

kHannig et al. (2007)

'Thamdrup et al. (2019)

mLi et al. (2015).

"Lam et al. (2009).

Lam et al. (2009).

Michiels et al. (2017).

Bohlen et al. (2011)

"Bonaglia et al. (2016).

'Thompson et al. (2019)

${ }^{5}$ Marschall et al. (2010).

'Garcia-Robledo et al. (2017)

$50 \%$ of the ocean may have been suboxic during the Mesoproterozoic (Reinhard et al., 2013), and surface water oxygen levels were likely high enough to efficiently oxidize ammonium and nitrite to nitrate (Bristow et al., 2016; Hardisty et al., 2017). However, the rock record indicates that nitrate concentrations were low in offshore waters (Koehler et al., 2017), which means that nitrite and nitrate did not accumulate, but were rapidly assimilated or re-reduced to $\mathrm{N}_{2}$ or ammonium at the chemocline within accumulating organic particles. Larger particles form from physical aggregation of smaller particles below the mixed layer in parts of the modern ocean dominated by cyanobacteria and microalgae (Cavan et al., 2018). Presumably a similar process would provide particles to the deeper Proterozoic ocean. In Proterozoic suboxic waters, denitrification may have been confined to particles, whereas anammox, a free-living process, would perhaps have been relatively unimportant (Figure 3). The amount of denitrification in these suboxic waters would have depended on organic matter availability and likely on particle size, which are difficult to predict accurately. The largest difference in the suboxic microbial community between the Proterozoic compared to modern suboxic waters was likely the dominance of bacterial ammonium oxidizers, which have higher half saturation constants for ammonium and produce 
more $\mathrm{N}_{2} \mathrm{O}$ than modern ammonia oxidizing archaea (Goreau et al., 1980; Martens-Habbena et al., 2009; Kozlowski, Kits, et al., 2016; Hink et al., 2017) (Table 1). Partial denitrification in particles and bacterial ammonium oxidation in the water column would likely produce $\mathrm{N}_{2} \mathrm{O}$ under these conditions (Figure 2 and 3). The interfaces of these suboxic waters, including particles, would also promote microaerophilic metal oxidation (Clement et al., 2009; Barco et al., 2015).

\section{Nitrogen cycling in anoxic waters}

In modern oxygen deficient zones, where oxygen is below $10 \mathrm{nM}$ (Revsbech et al., 2009) and sulfide is not detectable, $\mathrm{N}$ cycling is closely linked to organic matter fluxes. Denitrification is dependent on organic matter (Ward et al., 2008; Babbin et al., 2014; Chang et al., 2014) (Ganesh et al., 2015), and anammox bacteria use ammonium produced from organic matter remineralization (Devol, 2003) (Ganesh et al., 2015). Nitrate reduction to nitrite is the dominant rate process in the anoxic water column (Lam et al., 2009), with $~ 80 \%$ of the microbes present containing nitrate reduction genes in the ETNP (Fuchsman et al., 2017). However, nitrate reduction is heterotrophic and nitrate reduction rates are still linked to organic matter fluxes (Ganesh et al., 2015). In the ETSP and ETNP oxygen deficient zones, denitrification genes as a whole were enriched in the particulate fraction compared to free-living fraction (Ganesh et al., 2014, 2015; Fuchsman et al., 2017) though at least one denitrifier specialized in the ODZ water column rather than particles (Fuchsman et al., 2017). Low levels of autotropic dentrification with methane have also been detected in an oxygen deficient zone (Thamdrup et al., 2019). Cryptic sulfate reduction and S-oxidizing autotrophic denitrification was found in the coastal ETSP and proposed to be due to more reducing conditions in particles (Canfield et al., 2010; Stewart et al., 2012). Additionally, S-oxidizing denitrifiers as well as sulfate reducers were identified as particle-attached in the offshore ETNP ODZ and in the suboxic but not sulfidic water column of the Black Sea (Fuchsman, Murray, et al., 2012; Fuchsman et al., 2017; Saunders et al., 2019). However, the majority of denitrification in oxygen deficient zones is heterotrophic (Fuchsman et al., 2017; Thamdrup et al., 2019). $\mathrm{N}_{2} \mathrm{O}$ concentrations in oxygen deficient zones are some of the lowest in the ocean because $\mathrm{N}_{2} \mathrm{O}$ is consumed by the denitrifiers under anoxic conditions (Casciotti et al., 2018).

The Proterozoic deep ocean is thought to have been at least $30-40 \%$ and possibly up to $100 \%$ anoxic (Reinhard et al., 2013). In the Paleoproterozoic, abundant organic matter and nitrate would likely have stimulated massive $\mathrm{N}_{2}$ production by denitrification. The importance of anammox would have depended on the availability of ammonium, which was probably high due to extensive decay of abundant organic matter within sediments and in the water column. In Mesoproterozoic oxygen deficient waters, geochemical data suggest that organic matter and nitrate were much less abundant (Bekker and Holland, 2012; Kipp and Stüeken, 2017; Koehler et al., 2017; Reinhard et al., 2017; Crockford et al., 2018). Since nitrate could have been limiting, the ability of bacterial ammonium oxidizers to oxidize ammonium at low oxygen concentration could have been critical to this ecosystem. As nitrate reduction and dentrification are generally fueled by organic matter, rates of active $\mathrm{N}$ cycling were likely highest at the top of the oxygen deficient waters where organic matter fluxes from surfaces waters were greatest or where primary producers (cyanobacteria or anoxygenic photosynthesizers) could have been present. Anammox was also likely linked to ammonium production from this organic matter remineralization. Nitrate reduction can lead to either $\mathrm{N}_{2}$ production by denitrification/anammox or ammonium production by DNRA. High rates of DNRA have been measured in ferroginous lakes, greatly promoting productivity there (Michiels et al., 2017). It is unclear how important DNRA was in the Proterozoic ocean. Heterotrophic DNRA is not favored under the low organic matter conditions (Strohm et al., 2007) found in the Mesoproterozoic (Bekker and Holland, 2012; Kipp and Stüeken, 2017; Koehler et al., 2017; Reinhard et al., 2017; Crockford et al., 2018) and S oxidizing DNRA was not found at the sulfide interface of the Baltic Sea (Bonaglia et al., 2016). However, in the more productive Paleoproterozoic (Bekker and Holland, 2012; Kipp and Stüeken, 2017; Kipp et al., 2018), DNRA could have been more important. 
Some potentially large differences between the anoxic Proterozoic ocean and modern ODZs could be a greater importance of biological nitrate reduction with iron, Fe-ammox and of autotrophic denitrification with methane (Table 1). Due to higher concentrations of iron and some other metals, nitrate reduction from iron oxidation as well as from other metals such as arsenic likely occurred in this system (Straub et al., 1996; Scholz et al., 2016; Saunders et al., 2019). In these cases, ammonium from organic matter respiration would not be formed. Fe-ammox where ammonium is oxidized with iron oxides could also have occurred (Li et al., 2015, 2018; Stüeken et al., 2016; Huang and Jaffé, 2018). The importance of autotrophic denitrification with methane in the anoxic waters of the Proterozoic would depend on the concentration of methane and nitrate in the ocean. The flux of methane from marine sediments during the Mesoproterozoic is predicted to be twice modern levels (Bjerrum and Canfield, 2011; Roberson et al., 2011). However, methane can also be oxidized anaerobically by sulfate, manganese oxides and iron oxides (Beal et al., 2009), which would all have been present in the Proterozoic. Autotrophic denitrification with methane is likely to have been more important in the Proterozoic than today, but is unlikely to be a dominant process.

\section{Nitrogen cycling in sulfidic waters}

The Baltic and Black Seas are meromictic basins that can be used as analogs for sulfidic marine margins in the Proterozoic ocean. In the Baltic Sea, where conditions are changeable due to periodic flushing with oxic waters, S-oxidizing autotrophic dentitrification dominates $\mathrm{N}_{2}$ production whenever nitrate concentrations overlap with the sulfidic zone and anammox has dominated when sulfide and nitrate do not overlap (Hannig et al., 2007). S-oxidizing autotrophic denitrification has also been identified during a sulfidic event on the Namibian shelf (Lavik et al., 2009). Under modern conditions, large concentrations of $\mathrm{N}_{2} \mathrm{O}$ are not produced during S-oxidizing autotrophic denitrification because $\mathrm{N}_{2} \mathrm{O}$ is consumed by the denitrifiers (Lavik et al., 2009). In the Black Sea, a stable meromictic basin where nitrate concentrations in surface waters are quite low (3-5 $\mu \mathrm{M}$ compared to $>20 \mu \mathrm{M}$ in modern ODZs; Fuchsman et al., 2008), nitrate and sulfide do not overlap. Sinking manganese oxides may separate oxygen and nitrate from sulfide in the Black Sea by consumption of oxygen in manganese oxide formation and consumption of sulfide in reaction with the sinking manganese oxides (Yakushev et al., 2009). The reduced manganese then diffuses upward and is reoxidized. These manganese oxides also oxidize iron as they sink, forming particles with both iron and phosphorus (Dellwig et al., 2010). Not only do these metal containing particles separate nitrate and sulfide, when they also coagulate with organic matter, they provide habitat for metal and S cycling microbes (Fuchsman et al., 2011; Fuchsman, Murray, et al., 2012).

In the Black Sea, ammonium upwelling into the suboxic zone from the sulfide zone can be oxidized to nitrite at very low oxygen concentrations, potentially by gammaproteobacterial ammonia oxidizers, and this nitrite can be used by anammox bacteria (Lam et al., 2007). Thus this upward flux of ammonium allows $\mathrm{N}_{2}$ production from anammox to occur consistently without regard to organic matter flux from surface waters (Fuchsman, Staley, et al., 2012; Kirkpatrick et al., 2012). Anammox bacteria were even found to be active in the upper sulfidic zone $\left(<10 \mu \mathrm{M} \mathrm{H}_{2} \mathrm{~S}\right.$; Kirkpatrick et al., 2012). However, in this system heterotrophic dentrification is still linked to high organic matter fluxes (Kirkpatrick et al., 2012; Fuchsman, Paul, et al., 2019). Thus, low oxygen waters above sulfidic regions have many potential sources of $\mathrm{N}_{2}$ production.

In areas of the Mesoproterozoic ocean where sulfide was present, anammox or autotrophic denitrification may have dominated, depending on the overlap of nitrate with dissolved sulfide. As nitrate concentrations were low in offshore waters in the Mesoproterozoic (Koehler et al., 2017), it seems likely that, like in the Black Sea, aerobic ammonium oxidation would utilize the consistent upward flux of ammonium from the sulfide zone to make nitrite and that anammox would use this nitrite and the upward flux of ammonium to dominate $\mathrm{N}_{2}$ production above offshore sulfidic waters (Figure 3 ). In this situation, nitrite is produced but does not accumulate. S-oxidizing autotrophic denitrification would likely have 
been more prevalent at the sulfide interface in coastal regions, where both nitrate and metal concentrations were likely more abundant (Figure 3).

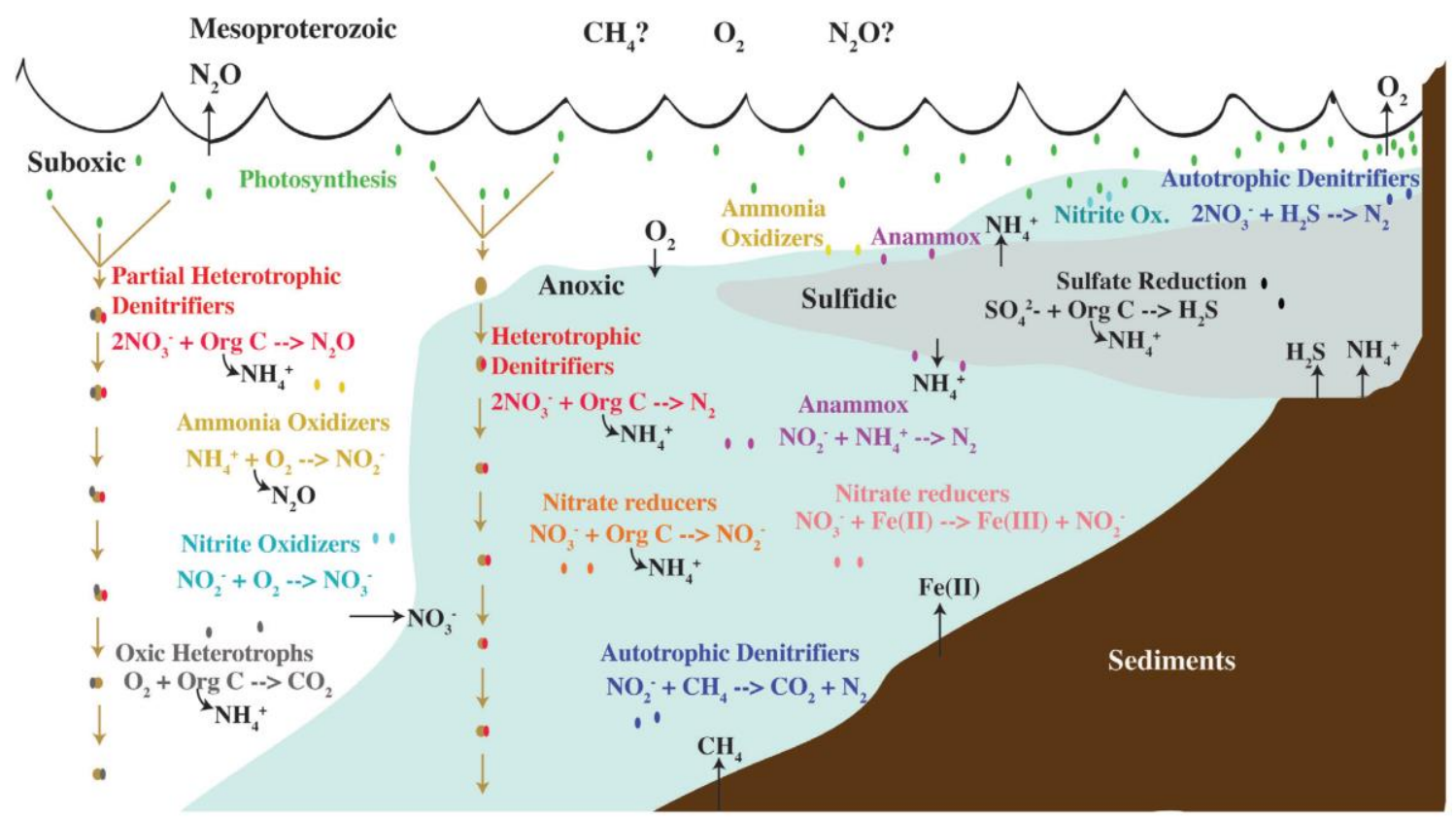

Figure 3: Schematic of microbial ecosystem during the Mesoproterozoic with sulfidic water in gray, anoxic water in blue, and suboxic water in white. Microbes are ovals that are colored similarly to the name of the process they represent. These ovals indicate whether these processes would occur on particles or the water column or at redox interfaces. Arrows indicate diffusion out of sediments, between redox zones, or to the atmosphere.

\section{$\mathrm{N}_{2} \mathrm{O}$ and the Proterozoic Ecosystem}

Solar luminosity was $83 \%$ of current levels during the early Proterozoic and increased to $95 \%$ over that billion year time period (Gough, 1981). However, the absence of glacial deposits indicates that global temperatures were temperate during the Mesoproterozoic (Crowell, 1999). About $10^{\circ} \mathrm{C}$ of additional warming would have been needed to maintain ice-free conditions in the Mesoproterozoic (Roberson et al., 2011). Four greenhouse gases have the potential to cause this warming: $\mathrm{CO}_{2}, \mathrm{CH}_{4}, \mathrm{~N}_{2} \mathrm{O}$ and $\mathrm{H}_{2} \mathrm{O}$. For $\mathrm{CO}_{2}$ to be the sole greenhouse gas warming the Proterozoic atmosphere, 100 times modern levels of $\mathrm{CO}_{2}$ would be necessary (Kasting, 1987), and the amount of atmospheric $\mathrm{CO}_{2}$ would have to decrease as the Sun's intensity increased. The constant isotopic composition of both carbonate and organic carbon throughout the Mesoproterozoic is inconsistent with $\mathrm{CO}_{2}$ levels declining with time (Shields and Veizer, 2002; Buick, 2007). Additionally, the use of carbon dioxide concentrating mechanisms by cyanobacteria at $1.2 \mathrm{Ga}$ indicate that carbon dioxide levels were not excessive during the Mesoproterozoic (Kah and Riding, 2007). Thus the presence of another greenhouse gas is necessary. Models indicate that the development of a UV-shielding ozone layer allowed some methane to be photolytically stable in the oxygenated Mesoproterozoic atmosphere (Claire et al., 2006). However, models of the Proterozoic biogeochemistry fail to produce enough methane to warm the atmosphere, because methane is rapidly consumed by sulfate reducing bacteria (Olson et al., 2016). Further, depleted $\delta^{13} \mathrm{C}_{\text {org }}$ values indicative of high marine methane concentrations in the rock record are not widespread (Shields and Veizer, 2002; Buick, 2007). It has been suggested that a terrestrial source of methane may solve this problem (Zhao et al., 2018), but observational evidence for this hypothesis is so far limited to the Archean (Flannery et al., 2016; Stüeken and Buick, 2018). Models with both methane and $\mathrm{N}_{2} \mathrm{O}$ jointly warming the atmosphere have been proposed (Roberson et al., 2011). 
Two alternative sources of $\mathrm{N}_{2} \mathrm{O}$ during the Mesoproterozoic have been considered. Buick (2007) argued that low copper concentrations in seawater limited the final step of heterotrophic denitrification in anoxic waters created an additional $\mathrm{N}_{2} \mathrm{O}$ flux, allowing $\mathrm{N}_{2} \mathrm{O}$ to be a key greenhouse gas in the Mesoproterozoic. The nitrous oxide reductase enzyme (Nos), which catalyses this step contains twelve copper atoms in its active site (Haltia et al., 2003). Experiments with denitrifying cultures have shown that copper-limited cultures of denitrifiers undergo incomplete denitrification at $10^{-15} \mathrm{M} \mathrm{Cu}(\mathrm{Granger}$ and Ward, 2003; Twining et al., 2007). Copper precipitates in the presence of sulfide, leaving the water column depleted in dissolved copper, which supports a model of low Proterozoic Cu levels. However, copper to titanium ratios over time do not show a decrease in copper concentrations during the Mesoproterozoic (Fru et al., 2016), making copper limitation of nitrous oxide reductase unlikely. Due to high iron concentrations in the Archaean and Proterozoic, abiotic chemodenitrification with iron, a process which predominately produces $\mathrm{N}_{2} \mathrm{O}$ not $\mathrm{N}_{2}$, has been suggested as a $\mathrm{N}_{2} \mathrm{O}$ source during the Mesoproterozoic (Stanton et al., 2018). Kinetic calculations indicate the possibility of this process in the Mesoproterozoic (Stanton et al., 2018), but more precise estimates of past nitrate and iron concentrations are needed to test if this $\mathrm{N}_{2} \mathrm{O}$ source would have been significant.

In the modern ocean, our understanding of the mechanisms creating $\mathrm{N}_{2} \mathrm{O}$ under low oxygen conditions has recently improved by the discovery that partial denitrification in particles is a significant source of $\mathrm{N}_{2} \mathrm{O}$ under suboxic conditions (Babbin et al., 2015; Ji et al., 2015). In the modern ocean, 0.5 $\mathrm{Tg}$ of the $3 \mathrm{Tg}-\mathrm{N}$ total $\mathrm{N}_{2} \mathrm{O}$ atmospheric fluxes is produced by partial denitrification in particles under suboxic water column conditions (Ji et al., 2018), which compose $7 \%$ of the modern ocean (Paulmier and Ruiz-Pino, 2009). Other marine $\mathrm{N}_{2} \mathrm{O}$ fluxes come from ammonium oxidation under low oxygen conditions. Since $50 \%$ of the ocean may have been suboxic during the Mesoproterozoic, simple scaling from $7 \%$ to $50 \%$ would imply that significant $\mathrm{N}_{2} \mathrm{O}$ fluxes $(\sim 20 \mathrm{Tg})$ from suboxic waters to the atmosphere likely occurred during that time period. However, models indicate that $40 \mathrm{Tg} \mathrm{N}_{2} \mathrm{O}$ were needed to support even $3^{\circ} \mathrm{C}$ of warming (with methane providing the remaining warming needed) (Roberson et al., 2011). Thus partial denitrification under suboxic conditions is unlikely to produce enough $\mathrm{N}_{2} \mathrm{O}$ to substantially warm the atmosphere of the Mesoproterozoic. The importance of $\mathrm{N}_{2} \mathrm{O}$ as a greenhouse gas in the Mesoproterozoic remains unclear.

\section{Conclusions}

Although a billion years of evolution has occurred since the Mesoproterozoic, including the evolution of single celled eukaryotic algae and multicellular organisms, the majority of microbial biogeochemical pathways, except archaeal ammonia oxidation, had already evolved by that time. The largest difference between the Proterozoic ocean and modern low oxygen marine systems were the high iron concentrations in the Proterozoic. In general, nitrate reduction and perhaps autotrophic denitrification from iron oxidation could have been a much more important process in the Proterozoic. Despite that, both heterotrophic and autotrophic pathways of the $\mathrm{N}$ cycle fundamentally depend on organic matter availability and remineralization. From microbially dominated photosynthesizers, low organic matter export fluxes are likely but not necessary. However, we note that organic matter production by oxic photosynthesis under low light or by anoxygenic photosynthesis using iron or reduced $\mathrm{S}$ can create important sources of organic matter directly in low oxygen waters, fueling $\mathrm{N}_{2}$ production and closing the $\mathrm{N}$ cycle. Additionally, partial denitrification inside sinking organic matter in suboxic waters, ammonia oxidation by bacteria, and potentially abiotic iron oxidation were likely important $\mathrm{N}_{2} \mathrm{O}$ sources to the atmosphere.

\section{Acknowledgements}

We would like to thank the three reviewers for their helpful comments and Matthew Hays for helpful comments on this manuscript prior to review. CAF was funded by University of Maryland Horn Point Laboratory start-up funds. 


\section{References}

Ader, M., Sansjofre, P., Halverson, G.P., Busigny, V., Trindade, R.I.F., Kunzmann, M., and Nogueira, A.C.R. (2014) Ocean redox structure across the Late Neoproterozoic Oxygenation Event: A nitrogen isotope perspective. Earth Planet Sci Lett 396: 1-13.

Ader, M., Thomazo, C., Sansjofre, P., Busigny, V., Papineau, D., Laffont, R., et al. (2016) Interpretation of the nitrogen isotopic composition of Precambrian sedimentary rocks: Assumptions and perspectives. Chem Geol 429: 93-110.

Algeo, T.J., Meyers, P.A., Robinson, R.S., Rowe, H., and Jiang, G.Q. (2014) Icehouse - greenhouse variations in marine denitrification. Biogeosciences 11: 1273-1295.

Anbar, A.D., Duan, Y., Lyons, T.W., Arnold, G.L., Kendall, B., Creaser, R.A., et al. (2007) A Whiff of Oxygen Before the Great Oxidation Event? Science (80- ) 317: 1903-1907.

Babbin, A.R., Bianchi, D., Jayakumar, A., and Ward, B.B. (2015) Rapid nitrous oxide cycling in the suboxic ocean. Science (80- ) 348: 1127-1129.

Babbin, A.R., Buchwald, C., Morel, F.M.M., Wankel, S.D., and Ward, B.B. (2020) Nitrite oxidation exceeds reduction and fixed nitrogen loss in anoxic Pacific waters. Mar Chem 224: 103814.

Babbin, A.R., Keil, R.G., Devol, A.H., and Ward, B.B. (2014) Organic matter stoichiometry, flux, and oxygen control nitrogen loss in the ocean. Science (80- ) 344: 406.

Babbin, A.R., Peters, B.D., Mordy, C.W., Widner, B., Casciotti, K.L., and Ward, B.B. (2017) Multiple metabolisms constrain the anaerobic nitrite budget in the Eastern Tropical South Pacific. Global Biogeochem Cycles 31: 258-271.

Barco, R.A., Emerson, D., Sylvan, J.B., Orcutt, B.N., Meyers, E.J., Ramírez, G.A., et al. (2015) New Insight into Microbial Iron Oxidation as Revealed by the Proteomic Profile of an Obligate IronOxidizing Chemolithoautotroph. Appl Environ Microbiol 81: 5927-5937.

Beal, E.J., House, C.H., and Orphan, V.J. (2009) Manganese- and Iron-Dependent Marine Methane Oxidation. Science (80- ) 311: 184-187.

Bekker, A. and Holland, H.D. (2012) Oxygen overshoot and recovery during the early Paleoproterozoic. Earth Planet Sci Lett 317-318: 295-304.

Bergman, I.A. and Kolesov, G.M. (2012) Arsenic, Antimony, and Bismuth as Indicators of the Genesis of Ore Material in Early Precambrian Ferrous Quartzite Formations. Geochemistry Int 50: 816-831.

Bianchi, D., Weber, T.S., Kiko, R., and Deutsch, C. (2018) Global niche of marine anaerobic metabolisms expanded by particle microenvironments. Nat Geosci 11: 263-268.

Bjerrum, C.J. and Canfield, D.E. (2011) Towards a quantitative understanding of the late Neoproterozoic carbon cycle. Proc Natl Acad Sci U S A 108: 5542-5547.

Blättler, C.L., Claire, M.W., Prave, A.R., Kirsimäe, K., Higgins, J.A., Medvedev, P. V., et al. (2018) Two-billion-year-old evaporites capture Earth's great oxidation. Science (80- ) 323: 320-323.

Bohlen, L., Dale, A.W., Sommer, S., Mosch, T., Hensen, C., Noffke, A., et al. (2011) Benthic nitrogen cycling traversing the Peruvian oxygen minimum zone. Geochim Cosmochim Acta 75: 6094-6111.

Bonaglia, S., Klawonn, I., Brabandere, L. De, Deutsch, B., and Thamdrup, B. (2016) Denitrification and DNRA at the Baltic Sea oxic - anoxic interface: Substrate spectrum and kinetics. Limnol Oceanogr 61: 1900-1915.

Brewer, P.G. and Murray, J.W. (1973) Carbon, nitrogen and phosphorus in the Black Sea. Deep Sea Res 20: $803-818$.

Bristow, L.A., Callbeck, C.M., Larsen, M., Altabet, M.A., Dekaezemacker, J., Forth, M., et al. (2017) $\mathrm{N} 2$ production rates limited by nitrite availability in the Bay of Bengal oxygen minimum zone. Nat Geosci 10: 24-29.

Bristow, L.A., Dalsgaard, T., Tiano, L., Mills, D.B., Bertagnolli, A.D., Wright, J.J., et al. (2016) Ammonium and nitrite oxidation at nanomolar oxygen concentrations in oxygen minimum zone waters. Proc Natl Acad Sci USA 113: 10601-6. 
Brochier-Armanet, C., Deschamps, P., López-García, P., Zivanovic, Y., Rodríguez-Valera, F., and Moreira, D. (2011) Complete-fosmid and fosmid-end sequences reveal frequent horizontal gene transfers in marine uncultured planktonic archaea. ISME J 5: 1291-1302.

Brussaard, C.P.D., Kuipers, B., and Veldhuis, M.J.W. (2005) A mesocosm study of Phaeocystis globosa population dynamics: I. Regulatory role of viruses in bloom control. Harmful Algae 4: 859-874.

Buchwald, C., Santoro, A.E., Stanley, R.H.R., and Casciotti, K.L. (2015) Nitrogen cycling in the secondary nitrite maximum of the eastern tropical North Pacific off Costa Rica. Global Biogeochem Cycles 29: 2061-2081.

Buick, R. (2007) Did the Proterozoic 'Canfield Ocean' cause a laughing gas greenhouse? Geobiology 5: 97-100.

Burdige, D.J. (1993) The biogeochemistry of manganese and iron reduction in marine sediments. Earth Sci Rev 35: 249-284.

Butterfield, N.J. (2015) Proterozoic Photosynthesis - A critical review. Palaeontology 58: 953-972.

Camacho, A., Walter, X.A., Picazo, A., and Zopfi, J. (2017) Photoferrotrophy: Remains of an Ancient Photosynthesis in Modern Environments. Front Microbiol 8: 323.

Canfield, D.E., Stewart, F.J., Thamdrup, B., De Brabandere, L., Dalsgaard, T., DeLong, E.F., et al. (2010) A Cryptic Sulfur Cycle in Oxygen-Minimum-Zone Waters off the Chilean Coast. Science (80- ) 330: 1375-1377.

Casciotti, K.L., Forbes, M., Vedamati, J., Peters, B.D., Martin, T.S., and Mordy, C.W. (2018) Nitrous oxide cycling in the Eastern Tropical South Pacific as inferred from isotopic and isotopomeric data. Deep Res Part II 156: 155-167.

Catling, D.C. (2014) 6.7 The Great Oxidation Event Transition. In Treatise on Geochemistry 2nd Edition. Elsevier Ltd, pp. 177-195.

Cavan, E.L., Giering, S.L.C., Wolff, G.A., Trimmer, M., and Sanders, R. (2018) Alternative Particle Formation Pathways in the Eastern Tropical North Pacific' s Biological Carbon Pump. Jounral Geophys Res Biogeosciences 123: 2198-2211.

Cavan, E.L., Trimmer, M., Shelley, F., and Sanders, R. (2017) Remineralization of particulate organic carbon in an ocean oxygen minimum zone. Nat Commun 8: 14847.

Cepeda-Morales, J., Beier, J., Gaxiola-Castro, G., Lavin, M.F., and Godinez, V.M. (2009) Effect of the oxygen minimum zone on the second chlorophyll maximum in the Eastern Tropical Pacific off Mexico. Ciencias Mar 35: 389-403.

Cernadas-Martín, S., Suter, E.A., Scranton, M.I., Astor, Y., and Taylor, G.T. (2017) Aerobic and anaerobic ammonium oxidizers in the Cariaco Basin: Distributions of major taxa and nitrogen species across the redoxcline. Aquat Microb Ecol 79: 31-48.

Chang, B.X., Rich, J.R., Jayakumar, A., Naik, H., Pratihary, A.K., Keil, R.G., et al. (2014) The effect of organic carbon on fixed nitrogen loss in the eastern tropical South Pacific and Arabian Sea oxygen deficient zones. Limnol Oceanogr 59: 1267-1274.

Cheng, C., Busigny, V., Ader, M., Thomazo, C., Chaduteau, C., and Philippot, P. (2019) Nitrogen isotope evidence for stepwise oxygenation of the ocean during the Great Oxidation Event. Geochim Cosmochim Acta 261: 224-247.

Chiu, B.K., Kato, S., McAllister, S.M., Field, E.K., and Chan, C.S. (2017) Novel pelagic iron-oxidizing Zetaproteobacteria from the Chesapeake Bay oxic-anoxic transition zone. Front Microbiol 8: 1280.

Claire, M.W., Catling, D.C., and Zahnle, K.J. (2006) Biogeochemical modelling of the rise in atmospheric oxygen. Geobiology 4: 239-269.

Clement, B.G., Luther, G.W., and Tebo, B.M. (2009) Rapid, oxygen-dependent microbial Mn (II) oxidation kinetics at sub-micromolar oxygen concentrations in the Black Sea suboxic zone. Geochim Cosmochim Acta 73: 1878-1889.

Crockford, P.W., Hayles, J.A., Bao, H., Planavsky, N.J., Bekker, A., Fralick, P.W., et al. (2018) Triple oxygen isotope evidence for limited mid-Proterozoic primary productivity. Nature 559: 613-616. 
Crowe, S.A., Jones, C., Katsev, S., Neill, A.H.O., Sturm, A., Canfield, D.E., et al. (2008) Photoferrotrophs thrive in an Archean Ocean analogue. Proc Natl Acad Sci U S A 105: 1593815943.

Crowe, S.A., Maresca, J.A., Jones, C., Sturm, A., Henny, C., and Fowle, D.A. (2014) Deep-water anoxygenic photosythesis in a ferruginous chemocline. Geobiology 12: 322-339.

Crowe, S.A., Paris, G., Katsev, S., Jones, C., Kim, S.-T., Zerkle, A.L., et al. (2014) Sulfate was a trace constituent of Archean seawater. Science (80- ) 346: 735-740.

Crowell, J.C. (1999) Pre-Mesozoic Ice Ages: Their Bearing on Understanding the Climate System, Boulder, CO: Geological Society of America.

Daines, S.J., Mills, B.J.W., and Lenton, T.M. (2017) Atmospheric oxygen regulation at low Proterozoic levels by incomplete oxidative weathering of sedimentary organic carbon. Nat Commun 8: 14379.

Dale, A.W., Sommer, S., Lomnitz, U., Bourbonnais, A., and Wallmann, K. (2016) Biological nitrate transport in sediments on the Peruvian margin mitigates benthic sulfide emissions and drives pelagic N loss during stagnation events. Deep Res Part I 112: 123-136.

Dalsgaard, T., Stewart, F.J., Thamdrup, B., Brabandere, L. De, Revsbech, P., and Ulloa, O. (2014) Oxygen at Nanomolar Levels Reversibly Suppresses Process Rates and Gene Expression in Anammox and Denitrification in the Oxygen Minimum Zone off Northern Chile. MBio 5: e0196614.

Dekas, A.E., Poretsky, R.S., and Orphan, V.J. (2009) Deep-sea archaea fix and share nitrogen in methane-consuming microbial consortia. Science (80- ) 326: 422-6.

Dellwig, O., Leipe, T., Ma, C., Glockzin, M., Pollehne, F., Schnetger, B., et al. (2010) A new particulate $\mathrm{Mn}-\mathrm{Fe}-\mathrm{P}$-shuttle at the redoxcline of anoxic basins. Geochim Cosmochim Acta 74: 7100-7115.

Derry, L.A. (2015) Causes and consequences of mid-Proterozoic anoxia. Geophys Res Lett 42: 85388546.

Devol, A.H. (2015) Denitrification, Anammox, and N2 Production in Marine Sediments. Annu Rev Mar Sci 7: 403-423.

Devol, A.H. (2003) Solution to a marine mystery. Nature 422: 575.

Diamond, C.W. and Lyons, T.W. (2018) Mid-Proterozoic redox evolution and the possibility of transient oxygenation events. Emerg Top Life Sci 2: 235-245.

Dilling, L. and Alldredge, A.L. (2000) Fragmentation of marine snow by swimming macrozooplankton : A new process impacting carbon cycling in the sea. Deep Res Part I 47: 1227-1245.

Eady, R.R. (1996) Structure-function relationship of alternative nitrogenases. Chem Rev 96: 3013-3030.

Ediger, D., Murray, J.W., and Y1lmaz, A. (2019) Phytoplankton biomass , primary production and chemoautotrophic production of the Western Black Sea in April 2003. J Mar Syst 198: 103183.

Ettwig, K., Butler, M., Le Paslier, D., Pelletier, E., Mangenot, S., Kuypers, M., et al. (2010) Nitritedriven anaerobic methane oxidation by oxygenic bacteria. Nature 464: 543.

Fang, X., Liu, Y., Zhao, Y., Chen, Y., Liu, R., Qin, Q.L., et al. (2019) Transcriptomic responses of the marine cyanobacterium Prochlorococcus to viral lysis products. Environ Microbiol 21: 2015-2028.

Farnelid, H., Bentzon-Tilia, M., Andersson, A.F., Bertilsson, S., Jost, G., Labrenz, M., et al. (2013) Active nitrogen-fixing heterotrophic bacteria at and below the chemocline of the central Baltic Sea. ISME J 7: 1413-23.

Farquhar, J., Savarino, J., Airieau, S., and Thiemens, M.H. (2001) Observation of wavelength-sensitive mass-independen sulfur isotope effects during SO2 photolysis: Implications for the early atmosphere. J Geophys Res 106: 32829-32839.

Fernandez, C., Farías, L., and Ulloa, O. (2011) Nitrogen fixation in denitrified marine waters. PLoS One 6: e20539.

Flannery, D.T., Allwood, A.C., and Kranendonk, M.J. Van (2016) Lacustrine facies dependence of highly 13C-depleted organic matter during the global age of methanotrophy. Precambrian Res $\mathbf{2 8 5}$ : 216-241. 
Fru, E.C., Arvestål, E., Callac, N., Albani, A. El, Kilias, S., Argyraki, A., and Jakobsson, M. (2015) Arsenic stress after the Proterozoic glaciations. Sci Rep 5: 17789.

Fru, E.C., RodrÃ-Guez, N.P., Partin, C.A., Lalonde, S. V., Andersson, P., Weiss, D.J., et al. (2016) Cu isotopes in marine black shales record the Great Oxidation Event. Proc Natl Acad Sci U S A 113: 4941-4946.

Fuchsman, C.A., Devol, A.H., Saunders, J.K., McKay, C., and Rocap, G. (2017) Niche Partitioning of the N cycling microbial community of an offshore Oxygen Deficient Zone. Front Microbiol 8: 2384.

Fuchsman, C.A., Kirkpatrick, J.B., Brazelton, W.J., Murray, J.W., and Staley, J.T. (2011) Metabolic strategies of free-living and aggregate-associated bacterial communities inferred from biologic and chemical profiles in the Black Sea suboxic zone. FEMS Microbiol Ecol 78: 586-603.

Fuchsman, C.A., Murray, J.W., and Konovalov, S.K. (2008) Concentration and natural stable isotope profiles of nitrogen species in the Black Sea. Mar Chem 111: 90-105.

Fuchsman, C.A., Murray, J.W., and Staley, J.T. (2012) Stimulation of autotrophic denitrification by intrusions of the Bosporus Plume into the anoxic Black Sea. Front Microbiol 3: 257.

Fuchsman, C.A., Palevsky, H.I., Widner, B., Duffy, M., Carlson, M.C.G., Neibauer, J.A., et al. (2019) Cyanobacteria and cyanophage contributions to carbon and nitrogen cycling in an oligotrophic oxygen-deficent zone. ISME J 13: 2714-2726.

Fuchsman, C.A., Paul, B., Staley, J.T., Yakushev, E. V., and Murray, J.W. (2019) Detection of Transient Denitrification During a High Organic Matter Event in the Black Sea. Global Biogeochem Cycles 33: $143-162$.

Fuchsman, C.A., Staley, J.T., Oakley, B.B., Kirkpatrick, J.B., and Murray, J.W. (2012) Free-living and aggregate-associated Planctomycetes in the Black Sea. FEMS Microbiol Ecol 80: 402-416.

Fuhrman, J.A. (1999) Marine viruses and their biogeochemical and ecological effects. Nature 399: 541548.

Ganesh, S., Bristow, L.A., Larsen, M., Sarode, N., Thamdrup, B., and Stewart, F.J. (2015) Size-fraction partitioning of community gene transcription and nitrogen metabolism in a marine oxygen minimum zone. ISME J 9: 2682-2696.

Ganesh, S., Parris, D.J., DeLong, E.F., and Stewart, F.J. (2014) Metagenomic analysis of sizefractionated picoplankton in a marine oxygen minimum zone. ISME J 8: 187-211.

Garcia-Robledo, E., Padilla, C.C., Aldunate, M., Stewart, F.J., Ulloa, O., Paulmier, A., et al. (2017) Cryptic oxygen cycling in anoxic marine zones. Proc Natl Acad Sci 114: 8319-8324.

Gaye, B., Nagel, B., Dähnke, K., Rixen, T., and Emeis, K.C. (2013) Evidence of parallel denitrification and nitrite oxidation in the ODZ of the Arabian Sea from paired stable isotopes of nitrate and nitrite. Global Biogeochem Cycles 27: 1059-1071.

Glass, J.B., Kretz, C.B., Ganesh, S., Ranjan, P., Seston, S.L., Buck, K.N., et al. (2015) Meta-omic signatures of microbial metal and nitrogen cycling in marine oxygen minimum zones. Front Microbiol 6: Article 998.

Glass, J.B., Wolfe-Simon, F., and Anbar, D. (2009) Coevolution of metal availability and nitrogen assimilation in cyanobacteria and algae. Geobiology 7: 100-123.

Glaubitz, S., Labrenz, M., Jost, G., and Jürgens, K. (2010) Diversity of active chemolithoautotrophic prokaryotes in the sulfidic zone of a Black Sea pelagic redoxcline as determined by rRNA-based stable isotope probing. FEMS Microbiol Ecol 74: 32-41.

Godfrey, L. V and Falkowski, P.G. (2009) The cycling and redox state of nitrogen in the Archaean ocean. Nat Geosci 2: 725-729.

Gophna, U., Charlebois, R.L., and Doolittle, W.F. (2006) Ancient lateral gene transfer in the evolution of Bdellovibrio bacteriovorus. Trends Microbiol 14: 64-69.

Goreau, T.J., Kaplan, W.A., and Wofsy, S.C. (1980) Production of NO2-and N2O by nitrifying bacteria at reduced concentrations of oxygen. Appl Environ Microbiol 40: 526-532.

Gough, D.O. (1981) Solar interior structure and luminosity variations. Sol Phys 74: 21-34. 
van de Graaf, A.A., Bruijn, P. De, Robertson, L.A., Jetten, M.M., and Kuenen, J.G. (1996) Autotrophic growth of anaerobic ammonium-oxidizing micro-organisms in a fluidized bed reactor. Microbiology 142: 2187-2196.

van de Graaf, A.A., Bruijn, P. De, Robertson, L.A., Jetten, M.M., and Kuenen, J.G. (1997) Metabolic pathway of anaerobic ammonium oxidation on the basis of $\mathrm{I} 5 \mathrm{~N}$ studies in a fluidized bed reactor. Microbiology 143: 2415-2421.

Granger, J. and Ward, B.B. (2003) Accumulation of nitrogen oxides in copper-limited cultures of denitrifying bacteria. Limnol Oceanogr 48: 313-318.

Guidi, L., Stemmann, L., Jackson, G.A., Ibanez, F., Claustre, H., Legendre, L., et al. (2009) Effects of phytoplankton community on production, size and export of large aggregates: A world-ocean analysis. Limnol Oceanogr 54: 1951-1963.

Gumsley, A.P., Chamberlain, K.R., Bleeker, W., Söderlund, U., Kock, M.O. De, Larsson, E.R., and Bekker, A. (2017) Timing and tempo of the Great Oxidation Event. Proc Natl Acad Sci U S A 114: 1811-1816.

Guo, Q., Strauss, H., Kaufman, A.J., Schröder, S., Gutzmer, J., Wing, B., et al. (2009) Reconstructing Earth's surface oxidation across the Archean- Proterozoic transition. Geology 37: 399-402.

Haltia, T., Brown, K., Tegoni, M., Cambillau, C., Saraste, M., Mattila, K., and Djinovic-Carugo, K. (2003) Crystal structure of nitrous oxide reductase from Paracoccus denitrificans at 1.6 A resolution. Biochem J 88: 77-88.

Hannig, M., Lavik, G., Kuypers, M.M.M., Woebken, D., Martens-Habbena, W., and Jurgens, K. (2007) Shift from denitrification to anammox after inflow events in the central Baltic Sea. Limnol Oceanogr 52: 1336-1345.

Haqq-Misra, J.D., Domagal-Goldman, S.D., Kasting, P.J., and Kasting, J.F. (2008) A Revised, Hazy Methane Greenhouse for the Archean Earth. Astrobiology 8: 1127-1137.

Hardisty, D.S., Lu, Z., Bekker, A., Diamond, C.W., Gill, B.C., Jiang, G., et al. (2017) Perspectives on Proterozoic surface ocean redox from iodine contents in ancient and recent carbonate. Earth Planet Sci Lett 463: 159-170.

He, S., Tominski, C., Kappler, A., Behrens, S., and Roden, E.E. (2016) Metagenomic Analyses of the Autotrophic Fe(II)-Oxidizing, Nitrate- Reducing Enrichment Culture KS. Appl Environ Microbiol 82: 2656-2668.

Hegler, F., Posth, N.R., Jiang, J., and Kappler, A. (2008) Physiology of phototrophic iron ( II ) -oxidizing bacteria : implications for modern and ancient environments. FEMS Microbiol Ecol 66: 250-260.

Heller, M.I., Lam, P.J., Moffett, J.W., Till, C.P., Lee, J., Toner, B.M., and Marcus, M.A. (2017) Accumulation of $\mathrm{Fe}$ oxyhydroxides in the Peruvian oxygen deficient zone implies non-oxygen dependent Fe oxidation. Geochim Cosmochim Acta 211: 174-193.

Hendrix, R.W., Lawrence, J.G., Hatfull, G.F., and Casjens, S. (2000) The origins and ongoing evolution of viruses. Trends Microbiol 8: 504-508.

Hillesland, K.L., Lenski, R.E., and Velicer, G.J. (2007) Ecological variables affecting predatory success in Myxococcus xanthus. Microb Ecol 53: 571-578.

Hink, L., Nicol, G.W., and Prosser, J.I. (2017) Archaea produce lower yields of N2O than bacteria during aerobic ammonia oxidation in soil. Environ Microbiol 19: 4829-4837.

Holland, H.D. (1984) The chemical evolution of the atmosphere and oceans., Princeton, NJ: Princeton University Press.

Horak, R.E.A., Qin, W., Bertagnolli, A.D., Nelson, A., Heal, K.R., Han, H., et al. (2018) Relative impacts of light, temperature, and reactive oxygen on thaumarchaeal ammonia oxidation in the North Pacific Ocean. Limnol Oceanogr 63: 741-757.

Huang, S. and Jaffé, P.R. (2018) Isolation and characterization of an ammonium-oxidizing iron reducer: Acidimicrobiaceae sp. A6. PLoS One 13: e0194007.

Husson, J.M. and Peters, S.E. (2017) Atmospheric oxygenation driven by unsteady growth of the 
continental sedimentary reservoir. Earth Planet Sci Lett 460: 68-75.

James, H.L. and Trendall, A.F. (1982) Banded iron formation: Distribution in time and paleoenvironmental significance. In Mineral Deposits and the Evolution of the Biosphere. Springer Berlin Heidelberg, pp. 199-217.

Jensen, M.M., Lam, P., Revsbech, N.P., Nagel, B., Gaye, B., Jetten, M.S., and Kuypers, M.M. (2011) Intensive nitrogen loss over the Omani Shelf due to anammox coupled with dissimilatory nitrite reduction to ammonium. ISME J 5: 1660-1670.

Jensen, M.M., Petersen, J., Dalsgaard, T., and Thamdrup, B. (2009) Pathways, rates, and regulation of N2 production in the chemocline of an anoxic basin, Mariager Fjord, Denmark. Mar Chem 113: 102-113.

Ji, Q., Babbin, A.R., Jayakumar, A., Oleynik, S., and Ward, B.B. (2015) Nitrous oxide production by nitrification and denitrification in the Eastern Tropical South Pacific oxygen minimum zone. Geophys Res Lett 42: 10,755-764.

Ji, Q., Buitenhuis, E., Suntharalingam, P., Sarmiento, J.L., and Ward, B.B. (2018) Global Nitrous Oxide Production Determined by Oxygen Sensitivity of Nitrification and Denitrification. Global Biogeochem Cycles 32: 1790-1802.

Johnson, B.W., Poulton, S.W., and Goldblatt, C. (2017) Marine oxygen production and open water supported an active nitrogen cycle during the Marinoan Snowball Earth. Nat Commun 8: 1316.

Johnston, D.T., Wolfe-Simon, F., Pearson, A., and Knoll, A.H. (2009) Anoxygenic photosynthesis modulated Proterozoic oxygen and sustained Earth's middle age. Proc Natl Acad Sci U S A 106: $16925-16929$.

Kah, L.C. and Riding, R. (2007) Mesoproterozoic carbon dioxide levels inferred from calcified cyanobacteria. Geology 35: 799-802.

Kalvelage, T., Lavik, G., Lam, P., Contreras, S., Arteaga, L., Löscher, C.R., et al. (2013) Nitrogen cycling driven by organic matter export in the South Pacific oxygen minimum zone. Nat Geosci 6: 228234.

Kappler, A. and Pasquero, C. (2005) Deposition of banded iron formations by anoxygenic phototrophic Fe (II)-oxidizing bacteria. Geology 33: 865-868.

Kasting, J.F. (1987) Theoretical constraints on oxygen and carbon dioxide concentrations in the Precambrian atmosphere. Precambrian Res 34: 205-229.

Keil, R.G., Neibauer, J.A., Biladeau, C., Van Der Elst, K., and Devol, A.H. (2016) A multiproxy approach to understanding the "enhanced" flux of organic matter through the oxygen-deficient waters of the Arabian Sea. Biogeosciences 13: 2077-2092.

Kendall, B., Dahl, T.W., and Anbar, A.D. (2017) The Stable Isotope Geochemistry of Molybdenum. Rev Mineral Geochemistry 82: 683-732.

Kendall, B., Gordon, G.W., Poulton, S.W., and Anbar, A.D. (2011) Molybdenum isotope constraints on the extent of late Paleoproterozoic ocean euxinia. Earth Planet Sci Lett 307: 450-460.

Kipp, M.A., Lepland, A., and Buick, R. (2020) Redox fluctuations, trace metal enrichment and phosphogenesis in the $\sim 2.0$ Ga Zaonega Formation. Precambrian Res 343: 105716.

Kipp, M.A. and Stüeken, E.E. (2017) Biomass recycling and Earth's early phosphorus cycle. Sci Adv 3: eaao4795.

Kipp, M.A., Stüeken, E.E., Bekker, A., and Buick, R. (2017) Selenium isotopes record extensive marine suboxia during the Great Oxidation Event. Proc Natl Acad Sci 114: 875-880.

Kipp, M.A., Stüeken, E.E., Yun, M., Bekker, A., and Buick, R. (2018) Pervasive aerobic nitrogen cycling in the surface ocean across the Paleoproterozoic Era. Earth Planet Sci Lett 500: 117-126.

Kirkpatrick, J.B., Fuchsman, C.A., Yakushev, E., Staley, J.T., and Murray, J.W. (2012) Concurrent activity of anammox and denitrifying bacteria in the Black Sea. Front Microbiol 3: Article 256.

Kirkpatrick, J.B., Fuchsman, C.A., Yakushev, E. V., Egorov, A. V., Staley, J.T., and Murray, J.W. (2018) Dark N2 fixation: nifH expression in the redoxcline of the Black Sea. Aquat Microb Ecol 82: 43- 
58.

Kits, K.D., Jung, M.Y., Vierheilig, J., Pjevac, P., Sedlacek, C.J., Liu, S., et al. (2019) Low yield and abiotic origin of $\mathrm{N} 2 \mathrm{O}$ formed by the complete nitrifier Nitrospira inopinata. Nat Commun 10: 1836.

Klawonn, I., Bonaglia, S., Brüchert, V., and Ploug, H. (2015) Aerobic and anaerobic nitrogen transformation processes in N2-fixing cyanobacterial aggregates. ISME J 9: 1456-1466.

Klueglein, N. and Kappler, A. (2013) Abiotic oxidation of Fe (II) by reactive nitrogen species in cultures of the nitrate-reducing Fe (II) oxidizer Acidovorax sp. BoFeNl - questioning the existence of enzymatic Fe (II) oxidation. Geobiology 11: 180-190.

Koehler, M.C., Buick, R., and Barley, M.E. (2019) Nitrogen isotope evidence for anoxic deep marine environments from the Mesoarchean Mosquito Creek Formation, Australia. Precambrian Res 320: 281-290.

Koehler, M.C., Buick, R., Kipp, M.A., Stüeken, E.E., and Zaloumis, J. (2018) Transient surface ocean oxygenation recorded in the $\sim 2.66-G a$ Jeerinah Formation, Australia. Proc Natl Acad Sci U S A 115: 7711-7716.

Koehler, M.C., Stueken, E.E., Kipp, M.A., Buick, R., and Knoll, A.H. (2017) Spatial and temporal trends in Precambrian nitrogen cycling: A Mesoproterozoic offshore nitrate minimum. Geochim Cosmochim Acta 198: 315-337.

Kondo, Y. and Moffett, J.W. (2013) Dissolved Fe (II) in the Arabian Sea oxygen minimum zone and western tropical Indian Ocean during the inter-monsoon period. Deep Res Part I 73: 73-83.

Kondo, Y. and Moffett, J.W. (2015) Iron redox cycling and subsurface offshore transport in the eastern tropical South Pacific oxygen minimum zone. Mar Chem 168: 95-103.

Konhauser, K.O., Lalonde, S. V, Planavsky, N.J., Pecoits, E., Lyons, T.W., Mojzsis, S.J., et al. (2011) Aerobic bacterial pyrite oxidation and acid rock drainage during the Great Oxidation Event. Nature 478: $369-373$.

Konhauser, K.O., Planavsky, N.J., Hardisty, D.S., Robbins, L.J., and Warchola, T.J. (2017) Iron formations: A global record of Neoarchaean to Palaeoproterozoic environmental history. EarthScience Rev 172: 140-177.

Kozlowski, J.A., Kits, K.D., and Stein, L.Y. (2016) Comparison of nitrogen oxide metabolism among diverse ammonia-oxidizing bacteria. Front Microbiol 7: 1090.

Kozlowski, J.A., Stieglmeier, M., Schleper, C., Klotz, M.G., and Stein, L.Y. (2016) Pathways and key intermediates required for obligate aerobic ammonia-dependent chemolithotrophy in bacteria and Thaumarchaeota. ISME J 10: 1836-45.

Kranzler, C.F., Krause, J.W., Brzezinski, M.A., Edwards, B.R., Biggs, W.P., Maniscalco, M., et al. (2019) Silicon limitation facilitates virus infection and mortality of marine diatoms. Nat Microbiol 4: $1790-1797$.

Krause, A.J., Mills, B.J.W., Zhang, S., Planavsky, N.J., Lenton, T.M., and Poulton, S.W. (2018) Stepwise oxygenation of the Paleozoic atmosphere. Nat Commun 9: 4081.

Kump, L.R., Junium, C., Arthur, M.A., Brasier, A., Fallick, A., and Luo, G. (2011) Isotopic Evidence for Massive Oxidation of Organic Matter Following the Great Oxidation Event. Science (80- ) 334: 1694-1697.

Laakso, T.A. and Schrag, D.P. (2017) A theory of atmospheric oxygen. Geobiology 15: 366-384.

Laakso, T.A. and Schrag, D.P. (2019) Methane in the Precambrian atmosphere. Earth Planet Sci Lett 522: 48-54.

Laber, C.P., Hunter, J.E., Carvalho, F., Collins, J.R., Hunter, E.J., Schieler, B.M., et al. (2018) Coccolithovirus facilitation of carbon export in the North Atlantic. Nat Microbiol 3: 537-547.

Lalonde, S. V and Konhauser, K.O. (2014) Benthic perspective on Earth's oldest evidence for oxygenic photosynthesis. Proc Natl Acad Sci U S A 112: 995-1000.

Lam, P., Jensen, M.M., Lavik, G., McGinnis, D.F., Muller, B., Schubert, C.J., et al. (2007) Linking crenarchaeal and bacterial nitrification to anammox in the Black Sea. Proc Natl Acad Sci 104: 7104- 
7109.

Lam, P., Lavik, G., Jensen, M.M., van de Vossenberg, J., Schmid, M., Woebken, D., et al. (2009) Revising the nitrogen cycle in the Peruvian oxygen minimum zone. Proc Natl Acad Sci U S A 106: 4752-4757.

Lavik, G., Stuhrmann, T., Bruchert, V., Plas, A. Van Der, Mohrholz, V., Lam, P., et al. (2009) Detoxification of sulphidic African shelf waters by blooming chemolithotrophs. Nature 457: 581584.

Lee, C.-T.A., Yeung, L.Y., Mckenzie, N.R., Yokoyama, Y., Ozaki, K., and Lenardic, A. (2016) Twostep rise of atmospheric oxygen linked to the growth of continents. Nat Geosci 9: 417-424.

Lenton, T.M., Dahl, T.W., Daines, S.J., Mills, B.J.W., Ozaki, K., and Saltzman, M.R. (2016) Earliest land plants created modern levels of atmospheric oxygen. Proc Natl Acad Sci U S A 113: 9704 9709.

Li, X., Hou, L., Liu, M., Zheng, Y., Yin, G., Lin, X., et al. (2015) Evidence of Nitrogen Loss from Anaerobic Ammonium Oxidation Coupled with Ferric Iron Reduction in an Intertidal Wetland. Environ Sci Technol 49: 11560-11568.

Li, X., Huang, Y., Liu, H. wei, Wu, C., Bi, W., Yuan, Y., and Liu, X. (2018) Simultaneous Fe(III) reduction and ammonia oxidation process in Anammox sludge. J Environ Sci (China) 64: 42-50.

Lipschultz, F., Wofsy, S.C., Ward, B.B., Codispoti, L.A., Friedrich, G., and Elkins, J.W. (1990) Bacterial transformations of inorganic nitrogen in the oxygen- deficient waters of the Eastern Tropical South Pacific Ocean. Deep Sea Res 37: 1513-1541.

Llirós, M., Armisen, T.G., Darchambeau, F., Morana, C., Margarit, X.T., Inceoğlu, Ö., et al. (2015) Pelagic photoferrotrophy and iron cycling in a modern ferruginous basin. Sci Rep 5: 13803.

Lu, W., Ridgwell, A., Thomas, E., Hardisty, D.S., Luo, G., Algeo, T.J., et al. (2018) Late inception of a resiliently oxygenated upper ocean. Science (80- ) 177: 174-177.

Luo, G., Junium, C.K., Izon, G., Ono, S., Beukes, N.J., Algeo, T.J., et al. (2018) Nitrogen fixation sustained productivity in the wake of the Palaeoproterozoic Great Oxygenation Event. Nat Commun 9: 978.

Luo, G., Ono, S., Huang, J., Algeo, T.J., Li, C., Zhou, L., et al. (2015) Decline in oceanic sulfate levels during the early Mesoproterozoic. Precambrian Res 258: 36-47.

Lyons, T.W., Reinhard, C.T., and Planavsky, N.J. (2014) The rise of oxygen in Earth's early ocean and atmosphere. Nature 506: 307-315.

Mänd, K., Lalonde, S. V, Robbins, L.J., Thoby, M., Paiste, K., Kreitsmann, T., et al. (2020) Palaeoproterozoic oxygenated oceans following the Lomagundi - Jatuli Event. Nat Geosci 13: 302307.

Marquez-Artavia, A., Sanchez-Velasco, L., Barton, E.D., Paulmier, A., Santamaria-Del-Angel, E., and Beier, E. (2019) A suboxic chlorophyll-a maximum persists within the Pacific oxygen minimum zone off Mexico. Deep Sea Res Part II Top Stud Oceanogr 170: 104686.

Marschall, E., Jogler, M., Hessge, U., and Overmann, J. (2010) Large-scale distribution and activity patterns of an extremely low-light-adapted population of green sulfur bacteria in the Black Sea. Environ Microbiol 12: 1348-62.

Martens-Habbena, W., Berube, P.M., Urakawa, H., De La Torre, J.R., and Stahl, D.A. (2009) Ammonia oxidation kinetics determine niche separation of nitrifying Archaea and Bacteria. Nature 461: 976979.

Martens-Habbena, W., Qin, W., Horak, R.E.A., Urakawa, H., Schauer, A.J., Moffett, J.W., et al. (2015) The production of nitric oxide by marine ammonia-oxidizing archaea and inhibition of archaeal ammonia oxidation by a nitric oxide scavenger. Environ Microbiol 17: 2261-2274.

Martin, A.P., Condon, D.J., Prave, A.R., and Lepland, A. (2013) A review of temporal constraints for the Palaeoproterozoic large, positive carbonate carbon isotope excursion (the Lomagundi-Jatuli Event). Earth Sci Rev 127: 242-261. 
Martin, T.S. and Casciotti, K.L. (2017) Paired N and O isotopic analysis of nitrate and nitrite in the Arabian Sea oxygen deficient zone. Deep Res Part I Oceanogr Res Pap 121: 121-131.

Michiels, C.C., Darchambeau, F., Roland, F.A.E., Morana, C., Llirós, M., García-Armisen, T., et al. (2017) Iron-dependent nitrogen cycling in a ferruginous lake and the nutrient status of Proterozoic oceans. Nat Geosci 10: 217-221.

Mills, B., Lenton, T.M., and Watson, A.J. (2014) Proterozoic oxygen rise linked to shifting balance between seafloor and terrestrial weathering. Proc Natl Acad Sci U S A 111: 9073-9078.

Moisander, P.H., Beinart, R.A., Hewson, I., White, A.E., Johnson, K.S., Carlson, C.A., et al. (2010) Unicellular cyanobacterial distributions broaden the oceanic N2 fixation domain. Science (80- ) 327: $1512-4$.

Montoya, J.P., Holl, C.M., Zehr, J.P., Hansen, A., Villareal, T.A., and Capone, D.G. (2004) High rates of N2 fixation by unicellular diazotrophs in the oligotrophic Pacific Ocean. Nature 430: 1027-1031.

Van Mooy, B.A.S., Keil, R.G., and Devol, A.H. (2002) Impact of suboxia on sinking particulate organic carbon: Enhanced carbon flux and preferential degradation of amino acids via denitrification. Geochim Cosmochim Acta 66: 457-465.

Olson, S.L., Kump, L.R., and Kasting, J.F. (2013) Quantifying the areal extent and dissolved oxygen concentrations of Archean oxygen oases. Chem Geol 362: 35-43.

Olson, S.L., Reinhard, C.T., and Lyons, T.W. (2016) Limited role for methane in the mid-Proterozoic greenhouse. Proc Natl Acad Sci U S A 113: 11447-11452.

Oschlies, A., Koeve, W., Landol, A., and Kähler, P. (2019) Loss of fixed nitrogen causes net oxygen gain in a warmer future ocean. Nat Commun 10: 2805.

Ossa, F.O., Eickmann, B., Hofmann, A., Planavsky, N.J., Asael, D., Pambo, F., and Bekker, A. (2018) Two-step deoxygenation at the end of the Paleoproterozoic Lomagundi Event. Earth Planet Sci Lett 486: $70-83$.

Partin, C.A., Bekker, A., Planavsky, N.J., Scott, C.T., Gill, B.C., Li, C., et al. (2013) Large-scale fluctuations in Precambrian atmospheric and oceanic oxygen levels from the record of $U$ in shales. Earth Planet Sci Lett 370: 284-293.

Passow, U. and De La Rocha, C.L. (2006) Accumulation of mineral ballast on organic aggregates. Global Biogeochem Cycles 20: GB1013.

Paulmier, A. and Ruiz-Pino, D. (2009) Oxygen minimum zones (OMZs) in the modern ocean. Prog Oceanogr 80: 113-128.

Pavlov, A.A. and Kasting, J.F. (2002) Mass-Independent Fractionatino of Sulfur Isotopes in Archean Sediments : Strong Evidence for an Anoxic Archaen Atmosphere. Astrobiology 2: 27-41.

Peng, X., Fuchsman, C.A., Jayakumar, A., Oleynik, S., and Martens-habbena, W. (2015) Ammonia and nitrite oxidation in the Eastern Tropical North Pacific. Global Biogeochem Cycles 29: 2034-2049.

Penn, J., Weber, T., and Deutsch, C. (2016) Microbial functional diversity alters the structure and sensitivity of oxygen deficient zones. Geophys Reserach Lett 43: 9773-9780.

Penn, J.L., Weber, T., Chang, B.X., and Deutsch, C. (2019) Microbial ecosystem dynamics drive fluctuating nitrogen loss in marine anoxic zones. Proc Natl Acad Sci 116: 7220-7225.

Pennington, J.T., Mahoney, K.L., Kuwahara, V.S., Kolber, D.D., Calienes, R., and Chavez, F.P. (2006) Primary production in the eastern tropical Pacific: A review. Prog Oceanogr 69: 285-317.

Peters, B.D., Babbin, A.R., Lettmann, K.A., Mordy, C.W., Ulloa, O., Ward, B.B., and Casciotti, K.L. (2016) Vertical modeling of the nitrogen cycle in the eastern tropical South Pacific oxygen deficient zone using high-resolution concentration and isotope measurements. Global Biogeochem Cycles 30: GB005415.

Planavsky, N.J., Asael, D., Hofmann, A., Reinhard, C.T., Lalonde, S. V., Knudsen, A., et al. (2014) Evidence for oxygenic photosynthesis half a billion years before the Great Oxidation Event. Nat Geosci 7: 283-286.

Planavsky, N.J., Mcgoldrick, P., Scott, C.T., Li, C., Reinhard, C.T., Kelly, A.E., et al. (2011) Widespread 
iron-rich conditions in the mid-Proterozoic ocean. Nature 477: 448-451.

Planavsky, N.J., Reinhard, C.T., Isson, T.T., Ozaki, K., and Crockford, P.W. (2020) Large MassIndependent Oxygen Isotope Fractionations in Mid-Proterozoic Sediments : Astrobiology 20: 628636.

Planavsky, N.J., Reinhard, C.T., Wang, X., Thomson, D., McGoldrick, P., Rainbird, R.H., et al. (2014) Low Mid-Proterozoic atmospheric oxygen levels and the delayed rise of animals. Science (80- ) 346:.

Planavsky, N.J., Slack, J.F., Cannon, W.F., Connell, B.O., Isson, T.T., Asael, D., et al. (2018) Evidence for episodic oxygenation in a weakly redox-buffered deep mid-Proterozoic ocean. Chem Geol 483: 581-594.

Ploug, H. (2001) Small-scale oxygen fluxes and remineralization in sinking aggregates. Limnol Oceanogr 46: 1624-1631.

Ploug, H. and Bergkvist, J. (2015) Oxygen diffusion limitation and ammonium production within sinking diatom aggregates under hypoxic and anoxic conditions. Mar Chem 176: 142-149.

Ploug, H., Kiihl, M., Buchholz-cleven, B., and Jergensen, B.B. (1997) Anoxic aggregates- an ephemeral phenomenon in the pelagic environment? Aquat Microb Ecol 13: 285-294.

Poulton, S.W. and Canfield, D.E. (2011) Ferruginous conditions: a dominant feature of the ocean through Earth's history. Elements 7: 107-112.

Poulton, S.W., Fralick, P.W., and Canfield, D.E. (2010) Spatial variability in oceanic redox structure 1.8 billion years ago. Nat Geosci 3: 486-490.

Reinhard, C.T., Planavsky, N.J., Gill, B.C., Ozaki, K., Robbins, L.J., Lyons, T.W., et al. (2017) Evolution of the global phosphorus cycle. Nature 541: 386-389.

Reinhard, C.T., Planavsky, N.J., Olson, S.L., Lyons, T.W., and Erwin, D.H. (2016) Earth's oxygen cycle and the evolution of animal life. Proc Natl Acad Sci U S A 113: 8933-8938.

Reinhard, C.T., Planavsky, N.J., Robbins, L.J., Partin, C.A., Gill, B.C., Lalonde, S. V, et al. (2013) Proterozoic ocean redox and biogeochemical stasis. Proc Natl Acad Sci U S A 110: 5357-5362.

Ren, M., Feng, X., Huang, Y., Wang, H., Hu, Z., Clingenpeel, S., et al. (2019) Phylogenomics suggests oxygen availability as a driving force in Thaumarchaeota evolution. ISME J 13: 2150-2161.

Revsbech, N.P., Larsen, L.H., Gundersen, J., Dalsgaard, T., Ulloa, O., and Thamdrup, B. (2009) Determination of ultra-low oxygen concentrations in oxygen minimum zones by the STOX sensor. Limnol Oceanogr 7: 371-381.

Roberson, A.L., Roadt, J., Halevy, I., and Kasting, J.F. (2011) Greenhouse warming by nitrous oxide and methane in the Proterozoic Eon. Geobiology 9: 313-320.

Sánchez-Baracaldo, P. (2015) Origin of marine planktonic cyanobacteria. Sci Rep 5: 17418.

Saunders, J.K., Fuchsman, C.A., Mckay, C., and Rocap, G. (2019) Complete arsenic-based respiratory cycle in the marine microbial communities of pelagic oxygen-deficient zones. Proc Natl Acad Sci U S A 116: 9925-9930.

Schad, M., Konhauser, K.O., Sánchez-Baracaldo, P., Kappler, A., and Bryce, C. (2019) How did the evolution of oxygenic photosynthesis influence the temporal and spatial development of the microbial iron cycle on ancient Earth ? Free Radic Biol Med 140: 154-166.

Schnetzer, A. and Steinberg, D.K. (2002) Active transport of particulate organic carbon and nitrogen by vertically migrating zooplankton in the Sargasso Sea. Mar Ecol Prog Ser 234: 71-84.

Scholz, F. (2018) Identifying oxygen minimum zone-type biogeochemical cycling in Earth history using inorganic geochemical proxies. Earth-Science Rev 184: 29-45.

Scholz, F., Löscher, C.R., Fiskal, A., Sommer, S., Hensen, C., Lomnitz, U., et al. (2016) Nitratedependent iron oxidation limits iron transport in anoxic ocean regions. Earth Planet Sci Lett 454: 272-281.

Scott, C., Wing, B.A., Bekker, A., Planavsky, N.J., Medvedev, P., Bates, S.M., et al. (2014) Pyrite multiple-sulfur isotope evidence for rapid expansion and contraction of the early Paleoproterozoic 
seawater sulfate reservoir. Earth Planet Sci Lett 389: 95-104.

Scranton, M.I., Taylor, G.T., Thunell, R.C., Muller-Karger, F., Astor, Y., Swart, P., et al. (2020) Anomalous $\delta 13 \mathrm{C}$ in POC at the chemoautotrophy maximum in the Cariaco Basin. J Geophys Res Biogeosciences 125: e2019JG005276.

Shang, M., Tang, D., Shi, X., Zhou, L., Zhou, X., Song, H., and Jiang, G. (2019) A pulse of oxygen increase in the early Mesoproterozoic ocean at ca. 1.57-1.56 Ga. Earth Planet Sci Lett 527: 115797.

Shelford, E.J., Middelboe, M., Møller, E.F., and Suttle, C.A. (2012) Virus-driven nitrogen cycling enhances phytoplankton growth. Aquat Microb Ecol 66: 41-46.

Sheyn, U., Rosenwasser, S., Lehahn, Y., Barak-Gavish, N., Rotkopf, R., Bidle, K.D., et al. (2018) Expression profiling of host and virus during a coccolithophore bloom provides insights into the role of viral infection in promoting carbon export. ISME J 12: 704-713.

Shibata, A., Kogure, K., Koike, I., and Ohwada, K. (1997) Formation of submicron colloidal particles from marine bacteria by viral infection. Mar Ecol Prog Ser 155: 303-307.

Shields-Zhou, G., Street, G., and Och, L. (2011) The case for a Neoproterozoic Oxygenation Event: Geochemical evidence and biological consequences. GSA Today 21: 4-11.

Shields, G. and Veizer, J. (2002) Precambrian marine carbonate isotope database: Version 1.1. Geochemistry Geophys Geosystems 3: GC000266.

Singer, E., Emerson, D., Webb, E.A., Barco, R.A., Kuenen, J.G., Nelson, W.C., et al. (2011) Mariprofundus ferrooxydans $P V-1$ the first genome of a marine $\mathrm{Fe}(\mathrm{II})$ oxidizing Zetaproteobacterium. PLoS One 6: e25386.

Slemons, L.O., Murray, J.W., Resing, J., Paul, B., and Dutrieux, P. (2010) Western Pacific coastal sources of iron, manganese, and aluminum to the Equatorial Undercurrent. Global Biogeochem Cycles 24: GB3024.

Smetacek, V.S. (1985) Role of sinking in diatom life-history cycles : ecological, evolutionary and geological significance. Mar Biol 84: 239-251.

Sperling, E.A., Wolock, C.J., Morgan, A.S., Gill, B.C., Kunzmann, M., Halverson, G.P., et al. (2015) Statistical analysis of iron geochemical data suggests limited late Proterozoic oxygenation. Nature 523: 451-454.

Stanton, C.L., Reinhard, C.T., Kasting, J.F., Ostrom, N.E., Haslun, J.A., Lyons, T.W., and Glass, J.B. (2018) Nitrous oxide from chemodenitrification: A possible missing link in the Proterozoic greenhouse and the evolution of aerobic respiration. Geobiology 16: 597-609.

Steadman, J.A., Large, R.R., Blamey, N.J., Mukherjee, I., Corkrey, R., Danyushevsky, L. V, et al. (2020) Evidence for elevated and variable atmospheric oxygen in the Precambrian. Precambrian Res 343: 105722.

Steinberg, D.K., Goldthwait, S.A., and Hansell, D.A. (2002) Zooplankton vertical migration and the active transport of dissolved organic and inorganic nitrogen in the Sargasso Sea. Deep Res Part I 49: $1445-1461$.

Stewart, F.J., Ulloa, O., and DeLong, E.F. (2012) Microbial metatranscriptomics in a permanent marine oxygen minimum zone. Environ Microbiol 14: 23-40.

Stief, P., Kamp, A., Thamdrup, B., and Glud, R.N. (2016) Anaerobic nitrogen turnover by sinking diatom aggregates at varying ambient oxygen levels. Front Microbiol 7: 98.

Stockey, R.G., Cole, D.B., Planavsky, N.J., Loydell, D.K., Frýda, J., and Sperling, E.A. (2020) Persistent global marine euxinia in the early Silurian. Nat Commun 11: 1804.

Straub, K.L., Benz, M., Schink, B., and Widdel, F. (1996) Anaerobic, Nitrate-Dependent Microbial Oxidation of Ferrous Iron. Appl Environ Microbiol 62: 1458-1460.

Strohm, T.O., Griffin, B., Zumft, W.G., and Schink, B. (2007) Growth Yields in Bacterial Denitrification and Nitrate Ammonification. Appl Environ Microbiol 73: 1420-1424.

Strous, M., Kuenen, J.G., and Jetten, M.S.M. (1999) Key Physiology of Anaerobic Ammonium Oxidation. Appl Environ Microbiol 65: 3248-3250. 
Stüeken, E.E. (2013) A test of the nitrogen-limitation hypothesis for retarded eukaryote radiation: Nitrogen isotopes across a Mesoproterozoic basinal profile. Geochim Cosmochim Acta 120: 121139.

Stüeken, E.E. (2017) Selenium Isotopes as a Biogeochemical Proxy in Deep Time. Rev Mineral Geochemistry 82: 657-682.

Stüeken, E.E. and Buick, R. (2018) Environmental control on microbial diversification and methane production in the Mesoarchean. Precambrian Res 304: 64-72.

Stüeken, E.E., Buick, R., Guy, B.M., and Koehler, M.C. (2015) Isotopic evidence for biological nitrogen fixation by molybdenum-nitrogenase from 3.2 Gyr. Nature 520: 666-669.

Stüeken, E.E., Catling, D.C., and Buick, R. (2012) Contributions to late Archaean sulphur cycling by life on land. Nat Geosci 5: 722-725.

Stüeken, E.E., Kipp, M.A., Koehler, M.C., and Buick, R. (2016) The evolution of Earth's biogeochemical nitrogen cycle. Earth Sci Rev 160: 220-239.

Stukel, M.R., Ohman, M.D., Kelly, T.B., and Biard, T. (2019) The Roles of Suspension-Feeding and Flux-Feeding Zooplankton as Gatekeepers of Particle Flux Into the Mesopelagic Ocean in the Northeast Pacific. Front Mar Sci 6: 397.

Sun, X., Ji, Q., Jayakumar, A., and Ward, B.B. (2017) Dependence of nitrite oxidation on nitrite and oxygen in low-oxygen seawater. Geophys Res Lett 44: 7883-7891.

Sun, X., Kop, L.F.M., Lau, M.C.Y., Frank, J., Jayakumar, A., Lücker, S., and Ward, B.B. (2019) Uncultured Nitrospina-like species are major nitrite oxidizing bacteria in oxygen minimum zones. ISME J 13: 2391-2402.

Takai, K., Miyazaki, M., Nunoura, T., Hirayama, H., Oida, H., Furushima, Y., and Yamamoto, H. (2006) Sulfurivirga caldicuralii gen. nov., sp. nov., a novel microaerobic, thermophilic, thiosulfateoxidizing chemolithoautotroph, isolated from a shallow marine hydrothermal system occurring in a coral reef, Japan. Int J Syst Evol Microbiol 56: 1921-1929.

Tarhan, L.G. (2018) The early Paleozoic development of bioturbation — Evolutionary and geobiological consequences. Earth-Science Rev 178: 177-207.

Thamdrup, B., Steinsdóttir, H.G.R., Bertagnolli, A.D., Padilla, C.C., Patin, N. V, Garcia-Robledo, E., et al. (2019) Anaerobic methane oxidation is an important sink for methane in the ocean's largest oxygen minimum zone. Limnol Oceanogr 64: 2569-2585.

Thomalla, S.J., Poulton, A.J., Sanders, R., Turnewitsch, R., Holligan, P.M., and Lucas, M.I. (2008) Variable export fluxes and efficiencies for calcite, opal, and organic carbon in the Atlantic Ocean: A ballast effect in action? Global Biogeochem Cycles 22: GB1010.

Thomazo, C., Couradeau, E., and Garcia-Pichel, F. (2018) Possible nitrogen fertilization of the early Earth Ocean by microbial continental ecosystems. Nat Commun 9: 2530.

Thompson, K.J., Kenward, P.A., Bauer, K.W., Warchola, T., Gauger, T., Martinez, R., et al. (2019) Photoferrotrophy, deposition of banded iron formations, and methane production in Archean oceans. Sci Adv 5: eaav2869.

Tominski, C., Heyer, H., Lösekann-Behrens, T., Behrens, S., and Kapplera, A. (2018) Growth and Population Dynamics of the Anaerobic Fe(II)- Oxidizing and Nitrate-Reducing Enrichment Culture KS. Appl Environ Microbiol 84: e02173-17.

Tosca, N.J., Guggenheim, S., and Pufahl, P.K. (2016) An authigenic origin for Precambrian greenalite: Implications for iron formation and the chemistry of ancient seawater. GSA Bull 128: 511-530.

Twining, B.S., Mylon, S.E., and Benoit, G. (2007) Potential role of copper availability in nitrous oxide accumulation in a temperate lake. Limnol Oceanogr 52: 1354-1366.

Walter, X.A., Picazo, A., Miracle, M.R., Vicente, E., Camacho, A., Aragno, M., and Zopfi, J. (2014) Phototrophic Fe (II)-oxidation in the chemocline of a ferruginous meromictic lake. Front Microbiol 5: 713 .

Wang, D., Ling, H., Struck, U., Zhu, X., Zhu, M., He, T., et al. (2018) Coupling of ocean redox and 
animal evolution during the Ediacaran-Cambrian transition. Nat Commun 9: 2575.

Wang, Z., Wang, X., Shi, X., Tang, D., Stüeken, E.E., and Song, H. (2020) Coupled Nitrate and Phosphate Availability Facilitated the Expansion of Eukaryotic Life at Circa $1.56 \mathrm{Ga}$. J Geophys Res Biogeosciences Biogeosciences 125: e2019JG005487.

Ward, B.B., Tuit, C.B., Jayakumar, A., Rich, J.J., Moffett, J., and Naqvi, S.W.A. (2008) Organic carbon, and not copper, controls denitrification in oxygen minimum zones of the ocean. Deep Res Part I Oceanogr Res Pap 55: 1672-1683.

Widdel, F., Schnellt, S., Heisingt, S., Ehrenreich, A., Assmus, B., and Schink, B. (1993) Ferrous iron oxidation by anoxygenic phototrophic bacteria. Nature 362: 834-836.

Widner, B., Fuchsman, C.A., Chang, B.X., Rocap, G., and Mulholland, M.R. (2018) Utilization of urea and cyanate in waters overlying and within the eastern tropical north Pacific oxygen deficient zone. FEMS Microbiol Ecol 94: fiy138.

Widner, B., Mordy, C.W., and Mulholland, M.R. (2018) Cyanate distribution and uptake above and within the Eastern Tropical South Pacific oxygen deficient zone. Limnol Oceanogr 63: S177-S192.

Yakushev, E., Pakhomova, S., Sørenson, K., and Skei, J. (2009) Importance of the different manganese species in the formation of water column redox zones: Observations and modeling. Mar Chem 117: $59-70$.

Yang, J., Junium, C.K., Grassineau, N.V., Nisbet, E.G., Izon, G., Mettam, C., et al. (2019) Ammonium availability in the Late Archaean nitrogen cycle. Nat Geosci 12: 553-557.

Yilmaz, A., Coban-Yildiz, Y., Tellikarakoc, F., and Bologa, A. (2006) Surface and mid-water sources of organic carbon by photoautotrophic and chemoautotrophic production in the Black Sea. Deep Sea Res Part II Top Stud Oceanogr 53: 1988-2004.

Zakem, E.J., Mahadevan, A., Lauderdale, J.M., and Follows, M.J. (2020) Stable aerobic and anaerobic coexistence in anoxic marine zones. ISME J 14: 288-301.

Zehr, J.P. (2011) Nitrogen fixation by marine cyanobacteria. Trends Microbiol 19: 162-173.

Zerkle, A.L., House, C.H., Cox, R.P., and Canfield, D.E. (2006) Metal limitation of cyanobacterial N2 fixation and implications. Geobiology 4: 285-297.

Zerkle, A.L., Simon, W., Newton, R.J., Mettam, C., Mark, W., Bekker, A., and Junium, C.K. (2017) Onset of the aerobic nitrogen cycle during the Great Oxidation Event. Nature 542: 465-467.

Zhang, F., Lenton, T.M., Rey, Á., Romaniello, S.J., Chen, X., Planavsky, N.J., et al. (2020) Uranium isotopes in marine carbonates as a global ocean paleoredox proxy: A critical review. Geochim Cosmochim Acta.

Zhang, X., Sigman, D.M., Morel, F.M.M., and Kraepiel, A.M.L. (2014) Nitrogen isotope fractionation by alternative nitrogenases and past ocean anoxia. Proc Natl Acad Sci U S A 111: 4782-7.

Zhang, Y., Qin, W., Hou, L., Zakem, E.J., Wan, X., Zhao, Z., et al. (2020) Nitrifier adaptation to low energy flux controls inventory of reduced nitrogen in the dark ocean. 117: 4823-4830.

Zhao, M., Reinhard, C.T., and Planavsky, N. (2018) Terrestrial methane fluxes and Proterozoic climate. Geology 46: 139-142. 